\title{
SAR, QSAR and Docking of Anticancer Flavonoids and Variants: A Review
}

\author{
Luciana Scotti ${ }^{1}$, Francisco Jaime Bezerra Mendonça Junior ${ }^{2}$, Diogo Rodrigo Magalhaes Moreira ${ }^{3}$, \\ Marcelo Sobral da Silva ${ }^{1}$, Ivan R. Pitta ${ }^{4}$ and Marcus Tullius Scotti ${ }^{5, *}$
}

${ }^{1}$ Federal University of Paraíba, Centre for Biotechnology, 50670-910, João Pessoa, PB, Brazil; ${ }^{2}$ State University of Paraiba, Biological Science Department, Laboratory of Synthesis and Drug Delivery, 58070-450, João Pessoa, PB, Brazil; ${ }^{3}$ Centro de Pesquisas Gonçalo Moniz, Fundação Oswaldo Cruz, CEP 40296-710, Salvador, BA, Brazil; ${ }^{4}$ Federal University of Pernambuco, Departamento de Antibióticos, Recife-PE 50670-910, Brazil; ${ }^{5}$ Federal University of Paraíba, Department of Engineering and the Environment, Campus IV; 58297-000, Rio Tinto, PB, Brazil

\begin{abstract}
Flavonoids are phenolic compounds, secondary metabolites of plants that cause several benefits to our health, including helping the treatment against cancer. These pharmacological properties are associated with the ability of flavonoids in attenuating the generation of reactive oxygen species, acting as chelate compounds or affecting the oxi-redox cycle. In spite of the large number of information in term of SAR and QSAR, no recent review has tabulated and discussed in detail these data. In view of this, we bring here a detailed discussion of the structure-activity relationships (SAR) and quantitative structure-activity relationships (QSAR) models. We have also analyzed the correlation between the chemical structure of flavonoids and analogues to their anticancer activities. A large number of methodologies have been used to identify the characteristics of these compounds with their potential anticancer: multiple linear regression, principal components analysis, comparative molecular field analysis, comparative molecular similarity indices analysis, partial least squares, neural networks, configuration of classification and regression trees, Free-Wilson, docking; using topological, structural and enthalpies' descriptors. We also discussed the use of docking models, together with QSAR models, for the virtual screening of anticancer flavonoids. The importance of docking models to the medicinal chemistry of anticancer flavonoids has increased in the last decade, especially to help in identifying the structural determinants responsible for the activity. We tabulated here the most important examples of virtual screening determined for anticancer flavonoids and we highlighted the structural determinants. The mode of action, the most potent anticancer flavonoids and hints for the structural design of anticancer flavonoids are revised in details and provided here.
\end{abstract}

Keywords: Cancer, descriptors, docking, flavonoids, SAR, QSAR.

\section{INTRODUCTION}

Flavonoids are polyphenolic compounds present in the leaves, flowers and stems of more than 4,000 higher plants. In plants, these compounds provide protection against the ultraviolet radiation, pathogens and herbivores. Flavonoids act also as pigments, providing colors from red to violet, and attracting pollinating vectors $[1,2]$. In special, these compounds have therapeutic properties in the food, cosmetic, and medicine fields.

According to VAYA et al. (2003) and CARDOSO et al. (2005) [3, 4], this class of secondary metabolite exhibits the same chemical skeleton, therefore can be classified into five main groups as shown in Fig. (1).

The major groups of flavonoids are endowed with pharmacological properties. Among them, we can cite the anticancer properties, cardioprotective as the most relevant of them [5-9].

\footnotetext{
*Address correspondence to this author at the Federal University of Paraíba, Department of Engineering and the Environment, Campus IV; 58297-000, Rio Tinto, PB, Brazil; Tel/Fax: 83-55-9941-2680;

E-mail:mtscotti@ccae.ufpb.br
}

In spite of the extreme search for new anticancer drugs for medical application, cancer remains a leading cause of death. As the time of writing, the anticancer properties of flavonoids are the most explored. We can find a large number of examples where the flavone core was used during the structural planning.

Many studies have ascertained the mode of action and the functional properties of anticancer flavonoids, including the carcinogen bioactivation, cell signaling and cycle regulation, angiogenesis, oxidative stress and anti-inflammatory properties. Compelling data from laboratory studies, epidemiological investigations, and human clinical trials indicate that flavonoids have important effects on cancer chemoprevention and chemotherapy. Some of these functional properties include: carcinogen inactivation, antiproliferation, cell cycle arrest, induction of apoptosis and differentiation, inhibition of angiogenesis and, reversal of multidrug resistance or a combination of these mechanisms. Based on these results, flavonoids are promising anticancer agents [5-9].

Regarding the structural determinants of flavonoids and analogues for the anticancer properties, it is possible to identify relevant chemical descriptors and correlations between the flavonoid structures versus anticancer activity. In the 
light of this, we here aimed here to tabulate and analyze in detail most the existing literature describing structureactivity relationships (SAR), quantitative structure-activity relationships (QSAR) and docking studies of anticancer flavonoids [10].

\section{SAR}

The main functional property of flavonoids is their ability to act as antioxidants, preventing heart diseases and cancers. The mode of how flavonoids display antioxidant activity depends on two factors: the electron-proton transfer and the stabilization of the formed free radical. Phenolic antioxidant agents $(\mathrm{Ar}-\mathrm{OH})$ need to scavenger the produced free radicals faster than other endogenous molecules, thereby conferring protection for the cells. The protective effects of a flavonoid is due to its capacity into transferring electrons to free radicals, like as a metal chelator, therefore reducing tocoferoxyl radicals as well as inhibiting oxidases $[1,2,11]$.

The main reasons for the antioxidant activity of flavonoids in terms of magnitude are: the position and the number of phenol hydroxyl attached to the carbon skeleton, the physicochemical properties of other substituent, and the possibility of formation of intramolecular hydrogen bonds [12, 13].

It is well-know the location of the phenolic hydroxyl affects the magnitude of the antioxidant activity. It is also described that compounds containing the hydroxyl in para (position 4) are more potent than those substituted in ortho or meta (positions 2 and 3, respectively). The relationship between the number of phenolic hydroxyls and the antioxidant activity shows that the greater the number of hydroxyl groups greater is the antioxidant activity. As a result, di(most common) and tri-substituted compounds have higher antioxidant properties than the mono-hydroxylated ones [13, 14].

In compounds containing a heteroatom (nitrogen and oxygen), or a hydroxyl group located in ortho and/or para position are more potent antioxidant agents because of the resonance involving the pair of $\pi$ electrons of the heteroatom and the resulting phenoxyl radical [15].

In 2001, Pannala and colleagues (2001) [1] used pharmacokinetic data to evaluate the antioxidant capacity of flavone and flavonol derivatives (see Fig. 1). In view of this study, we can summarize important structural determinants:
- The position of the hydroxyl group in ring B is crucial for the antioxidant activity and cannot be removed. In regard to the position, a para position is better, while little or no activity is observed in ortho and meta positions;

- The presence of a second hydroxyl group in ring B enhances the antioxidant activity;

- The presence of two ortho-dihydroxy substitution on ring $\mathrm{B}$, and the double bond $\mathrm{C} 2-\mathrm{C} 3$ conjugated to the carbonyl group (C4) in ring $\mathrm{C}$ (as seen in flavones) is essential for the antioxidant activity;

- A hydroxyl group located in C3 of the ring $\mathrm{C}$ increases the antioxidant activity;

- The presence of a hydroxyl in C4 increases the antioxidant activity in compounds having a hydroxylin $\mathrm{C} 3$ because of the intense conjugation (resonance);

- Hydroxyl groups in positions C5 and C7 of the ring A have no importance;

- Compounds with three hydroxyl groups are more active than dihydroxyl compounds. The reason for is because these compounds adopt a mechanism of action involving electron donation, resulting to the formation of a semiquinone specie, and subsequently a quinine $[1,16]$.

The C2-C3 double bond also appears to be important for the anticancer activity, it is clear when we compare flavanones and flavones derivatives (Fig. 2). These flavonoid variants inhibit the breast cancer resistance protein (BCRP), a membrane efflux transporter that belongs to the ABC (ATP binding cassette) transporter superfamily. ABCG2 expression in cancer cells is related to the multidrug resistance process [16-18].

Two years later, it was reported the presence of a hydroxyl group in C-5 along to a methoxy group in C-3 are also important for the inhibitory activity of BCRP. The most active compounds identified were the ayanin and retusin (Fig. 3) [19].

In another interesting work, Cheng and colleagues (2002, 2003) $[14,21]$ compared the antioxidant properties of 15 phenolic compounds by molecular modeling. They found that gallic acid and pyrogallol (Fig. 4) exhibit a different reactivity and functional profile. In this model, gallic acid and pyrogallol were not predicted as antioxidant agents, be-
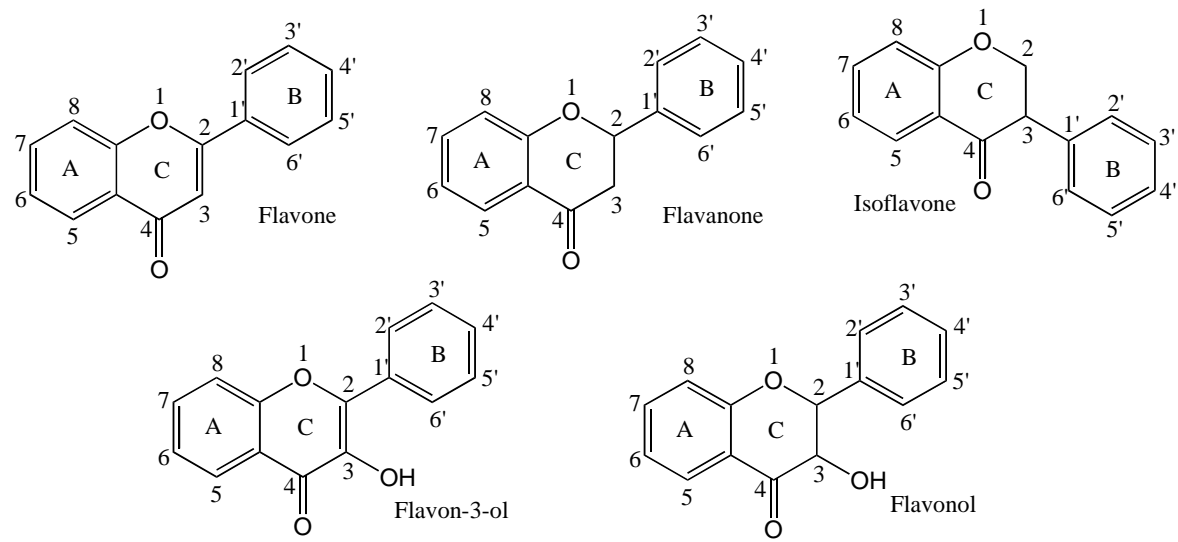

Fig. (1). Five main groups of flavonoids [3]. 


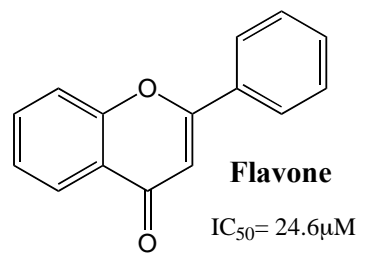

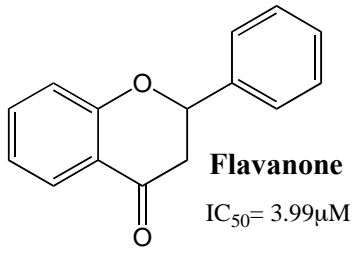<smiles>O=c1cc(-c2ccc(O)cc2)oc2cc(O)cc(O)c12</smiles><smiles>O=C1CC(c2ccc(O)cc2)Oc2cc(O)cc(O)c21</smiles>

Fig. (2). The presence of a $\mathrm{C} 2-\mathrm{C} 3$ double bond in flavonoids is required for flavonoids inhibiting BCRP.<smiles>COc1cc(O)c2c(=O)c(OC)c(-c3ccc(OC)c(O)c3)oc2c1</smiles><smiles>COc1cc(O)c2c(=O)c(OC)c(-c3ccc(OC)c(OC)c3)oc2c1</smiles>

Fig. (3). Chemical structure of ayanin and retusin.

cause of their significant pro-oxidant activity. An explanation is that these compounds may act as both antioxidants and pro-oxidant, it depends on used concentration as well as the source of free radicals. In fact, the reduction of $\mathrm{Fe}^{+3}$ into $\mathrm{Fe}^{+2}$ induced by these compounds affect the Fenton's reaction (Equation 1) as well as the generation of $\mathrm{OH} \bullet$ radicals. Following a Fenton's reaction and Haber-Weiss cycle, it is believed that an autoxidation and production of $\mathrm{H}_{2} \mathrm{O}_{2}$ by increasing the concentration of hydroxyl radicals is involved during the antioxidant properties of these flavonoids (Equation 2).

$$
\begin{aligned}
& \text { Equation } 1 \mathrm{Fe}^{2+}+\mathrm{H}_{2} \mathrm{O}_{2} \rightarrow \mathrm{Fe}^{3+}+\mathrm{OH}^{-}+\bullet \mathrm{OH} \\
& \text { Equation } 2 \mathrm{Fe}^{3+}+\mathrm{O}_{2} \longrightarrow \mathrm{Fe}^{2+}+\mathrm{O}_{2}
\end{aligned}
$$

Topical application of similar flavonoids and antioxidants reduce the oxidative damage induced by UV radiation. As a result, flavonoids prevent oxidative stress, reduce cell damage, which is worthy for a therapeutic application for skin cancer. However, this protection is most effective when there is penetration of antioxidant agents into deepest layers of the stratum corneum.<smiles>O=C(O)c1cc(O)c(O)c(O)c1</smiles>

Gallic acid<smiles>Oc1cccc(O)c1O</smiles>

Pyrogallol
Fig. (4). Chemical structure of gallic acid and pyrogallol.
It is evident that a topical formulation should exhibit an appropriated $\mathrm{C} \log \mathrm{P}$ [11], a parameter to be considered in the search for topical solutions that reduce the side effects of reactive oxygen species (ROS) [13]. In an analysis of aqueous solutions of caffeic and ferulic acid at $\mathrm{pH} 3.0$ and 7.2, it was observed that the penetration of the ferulic acid solution in the stratum corneum was higher than that seen for caffeic acid, thereby reducing the UV-induced erythema with greater efficiency. An explanation of this is because of the higher ferulic acid lipophilicity $($ CLOGP $=1.62)$ when compared to caffeic acid (CLOGP $=1.55)[22,23]$.

\section{QSAR}

\subsection{CoMFA, CoMSIA, PLS}

Topological and substructural descriptors have been recently employed in several anticancer QSAR studies using sets of small molecules of several classes with activities against brain tumor cells lines [24], anti colorectal cancer cells [25], breast cancer cell lines [26] and, human carcinoma of the nasopharynx [27]. Recently, some studies of Quantitative Structure-Disease Relationship (QSDR) used topological index to predict protein properties linked with colon cancer [28-30], human breast cancer [30], and antioxidant properties [31]. Topological descriptors have also been successfully employed to calculate predictive model using flavonoids. For instance, Farkas et al. (2004) [5] conducted a study with 36 flavonoids selected from the literature, including: flavonol, flavone, flavanone, dihydroflavonol, biflavanone, isoflavanone, and coumestrol. The antioxidant activities were determined by their ability to inhibit the $\beta$ carotenelinoleic acid in the model of heat-induced oxidation [32]. The theoretical models were built with the Statistica 
$5.5^{\circledR}$ program, and calculating the partial least squares projection of latent structures (PLS) method. The number of calculated descriptors was 147 , omitting which showed a correlation higher than 0.99 . The validation of the models was done by leave-one-out cross-validation cut-off (PRESS $=0.6253$, $\mathrm{R}^{2}=0.9888$ ). As advantage, the model was obtained with a short time machine and led to a high predictive of antioxidant activity as well as separating the various flavonoids groups.

A more recent work described the anticancer properties of 23 isoflavones (see Table 1), which featured the impor- tance of a methyl group in different positions for the anticancer properties [6].

The relationship between the structural properties of methoxyisoflavones and their anticancer activities in HCT116 cells were analyzed by CoMFA and CoMSIA. A PLS dataset was used in both the models to select the most significant descriptors that correlates to the interaction fields. The model $\left(\right.$ CoMFA q ${ }^{2}=0.783$; CoMSIA q $\left.{ }^{2}=0.540, \mathrm{r}^{2}=0.960\right)$ showed best cross-validation correlation coefficient or noncross-validation coefficient [6].

Table 1. Structures of 23 Isoflavones and their Biological Activities on the Clonogenic Survival Density of HCT116 Colon Cancer Cells [6].

\begin{tabular}{|c|c|c|c|c|c|c|c|c|c|}
\hline Number & Chemical name & R1 & $\mathbf{R 2}$ & R3 & $\mathbf{R 4}$ & R5 & R6 & $\mathbf{R} 7$ & Biol. \\
\hline 1 & 7-Methoxyisoflavone & $\mathrm{H}$ & $\mathrm{H}$ & $\mathrm{OCH}_{3}$ & $\mathrm{H}$ & $\mathrm{H}$ & $\mathrm{H}$ & $\mathrm{H}$ & 174 \\
\hline 2 & 6,7-Dimethoxyisoflavone & $\mathrm{H}$ & $\mathrm{OCH}_{3}$ & $\mathrm{OCH}_{3}$ & $\mathrm{H}$ & $\mathrm{H}$ & $\mathrm{H}$ & $\mathrm{H}$ & 26 \\
\hline 3 & 4',5-Dihydroxy-7-metoxyisoflavone(Prunetin) & $\mathrm{O}$ & $\mathrm{H}$ & $\mathrm{OCH}_{3}$ & $\mathrm{H}$ & $\mathrm{H}$ & $\mathrm{H}$ & $\mathrm{OH}$ & 78 \\
\hline 4 & 4',6-Dimethoxy-7-hydroxyisoflavone & $\mathrm{H}$ & $\mathrm{OCH}_{3}$ & $\mathrm{OH}$ & $\mathrm{H}$ & $\mathrm{H}$ & $\mathrm{H}$ & $\mathrm{OCH}_{3}$ & 287 \\
\hline 5 & 7-Hydroxy-6-mehtoxyisoflavone & $\mathrm{H}$ & $\mathrm{OCH}_{3}$ & $\mathrm{OH}$ & $\mathrm{H}$ & $\mathrm{H}$ & $\mathrm{H}$ & $\mathrm{H}$ & 188 \\
\hline 6 & $3^{\prime}, 4^{\prime}, 5,7-$ Tetramethoxyisoflavone & $\mathrm{OCH}_{3}$ & $\mathrm{H}$ & $\mathrm{OCH}_{3}$ & $\mathrm{H}$ & $\mathrm{H}$ & $\mathrm{OCH}_{3}$ & $\mathrm{OCH}_{3}$ & 233 \\
\hline 7 & 3',4',6,7-Tetramethoxyisoflavone & $\mathrm{H}$ & $\mathrm{OCH}_{3}$ & $\mathrm{OCH}_{3}$ & $\mathrm{H}$ & $\mathrm{H}$ & $\mathrm{OCH}_{3}$ & $\mathrm{OCH}_{3}$ & 44 \\
\hline 8 & $4^{\prime}, 7,8$-Trihydroxyisoflavone & $\mathrm{H}$ & $\mathrm{H}$ & $\mathrm{OH}$ & $\mathrm{OH}$ & $\mathrm{H}$ & $\mathrm{H}$ & $\mathrm{OH}$ & 108 \\
\hline 9 & 4',7,8-Trimethoxyisoflavone & $\mathrm{H}$ & $\mathrm{H}$ & $\mathrm{OCH}_{3}$ & $\mathrm{OCH}_{3}$ & $\mathrm{H}$ & $\mathrm{H}$ & $\mathrm{OCH}_{3}$ & 90 \\
\hline 10 & 3',4',7-Trimethoxyisoflavone & $\mathrm{H}$ & $\mathrm{H}$ & $\mathrm{OCH}_{3}$ & $\mathrm{H}$ & $\mathrm{H}$ & $\mathrm{OCH}_{3}$ & $\mathrm{OCH}_{3}$ & 193 \\
\hline 11 & 4'-Bromo-5,7-dimethoxyisoflavone & $\mathrm{OCH}_{3}$ & $\mathrm{H}$ & $\mathrm{OCH}_{3}$ & $\mathrm{H}$ & $\mathrm{H}$ & $\mathrm{H}$ & $\mathrm{Br}$ & 259 \\
\hline 12 & 2'-Chloro-5,7-dimethoxyisoflavone & $\mathrm{OCH}_{3}$ & $\mathrm{H}$ & $\mathrm{OCH}_{3}$ & $\mathrm{H}$ & $\mathrm{Cl}$ & $\mathrm{H}$ & $\mathrm{H}$ & 110 \\
\hline 13 & 3'-Chloro-5,7-dimethoxyisoflavone & $\mathrm{OCH}_{3}$ & $\mathrm{H}$ & $\mathrm{OCH}_{3}$ & $\mathrm{H}$ & $\mathrm{H}$ & $\mathrm{Cl}$ & $\mathrm{H}$ & 52 \\
\hline 14 & 4'-Chloro-5,7-dimethoxyisoflavone & $\mathrm{OCH}_{3}$ & $\mathrm{H}$ & $\mathrm{OCH}_{3}$ & $\mathrm{H}$ & $\mathrm{H}$ & $\mathrm{H}$ & $\mathrm{Cl}$ & 86 \\
\hline 15 & 4'-Chloro-7-hydroxy-8-methylisoflavone & $\mathrm{H}$ & $\mathrm{H}$ & $\mathrm{OH}$ & $\mathrm{CH}_{3}$ & $\mathrm{H}$ & $\mathrm{H}$ & $\mathrm{Cl}$ & 161 \\
\hline 16 & 4'-Chloro-7-methoxy-8-methylisoflavone & $\mathrm{H}$ & $\mathrm{H}$ & $\mathrm{OCH}_{3}$ & $\mathrm{CH}_{3}$ & $\mathrm{H}$ & $\mathrm{H}$ & $\mathrm{Cl}$ & 125 \\
\hline 17 & 2',6-Dichloro-7-methoxyisoflavone & $\mathrm{H}$ & $\mathrm{Cl}$ & $\mathrm{OCH}_{3}$ & $\mathrm{H}$ & $\mathrm{Cl}$ & $\mathrm{H}$ & $\mathrm{H}$ & 284 \\
\hline 18 & 4',7-Dimethoxy-8-methylisoflavone & $\mathrm{H}$ & $\mathrm{H}$ & $\mathrm{OCH}_{3}$ & $\mathrm{CH}_{3}$ & $\mathrm{H}$ & $\mathrm{H}$ & $\mathrm{OCH}_{3}$ & 142 \\
\hline 19 & 7-Hydroxy-8-methylisoflavone & $\mathrm{H}$ & $\mathrm{H}$ & $\mathrm{OH}$ & $\mathrm{CH}_{3}$ & $\mathrm{H}$ & $\mathrm{H}$ & $\mathrm{H}$ & 217 \\
\hline 20 & 7-Methoxy-8-methylisoflavone & $\mathrm{H}$ & $\mathrm{H}$ & $\mathrm{OCH}_{3}$ & $\mathrm{CH}_{3}$ & $\mathrm{H}$ & $\mathrm{H}$ & $\mathrm{H}$ & 138 \\
\hline 21 & 7-Methyl-2',4',6-trichloroisoflavone & $\mathrm{H}$ & $\mathrm{Cl}$ & $\mathrm{CH}_{3}$ & $\mathrm{H}$ & $\mathrm{Cl}$ & $\mathrm{H}$ & $\mathrm{Cl}$ & 262 \\
\hline 22 & 4'-Acetoxy-7-hydroxy-6-methoxyisoflavone & $\mathrm{H}$ & $\mathrm{OCH}_{3}$ & $\mathrm{OH}$ & $\mathrm{H}$ & $\mathrm{H}$ & $\mathrm{H}$ & OAc & 220 \\
\hline 23 & 7-Methoxy-5-methylisoflavone & $\mathrm{CH}_{3}$ & $\mathrm{H}$ & $\mathrm{OCH}_{3}$ & $\mathrm{H}$ & $\mathrm{H}$ & $\mathrm{H}$ & $\mathrm{H}$ & 134 \\
\hline
\end{tabular}


Using PLS analysis, another study aimed to identify a linear correlation between the antiproliferative activity against colorectal cells and the resulting field matrix of isoflavones. Counter maps calculated from CoMFA and CoMSIA analyses led to infer information in regard to the steric, electrostatic, hydrophobic, and $\mathrm{H}$-bond donor and acceptor effects, as seen in Fig. (5) [6].

Another investigation also used a similar model; however it has included 30 flavone, flavanones, isoflavones, and chalcones. This model was analyzed by CoMFA e CoMSIA [7]. As the biological parameter, all these 30 compounds were assayed in cancer cells (lymphomas, melanomas, breast, colon, ovarian, uterine cervix, prostate, thyroid, skin, esophagus and pancreatic cancer). However, this work also taken in account the ability of compounds to inhibit the expression of $\mathrm{NF}-\kappa \mathrm{B}$, a protein involved in inflammatory process. TNF $\alpha$ is a major pro-inflammatory cytokine and plays an essential role in the regulation of immune responses. It is suggested that $\mathrm{TNF} \alpha$ is acting as a target for cancer therapy [7, 33, 34].

Once again, the best CoMFA model was obtained by the region focusing method and showed cross-validated correlation coefficient $\left(\mathrm{q}^{2}=0.611\right)$ and non-cross-validated $\left(\mathrm{r}^{2}=\right.$ 0.969). This model predicted that, for a compound affects the secretion of TNF $\alpha$ and NF- $\kappa \mathrm{B}$ activation, it should contain an electronegative substituent at the $\mathrm{C}-5$ position of the $\mathrm{A}$ ring, a bulky substituent in the meta position of the B ring, as well as a hydrophobic substituent in the meta position of the $B$ ring [7].

Another important attempt to predict the anticancer properties of flavonoids relies on the understanding of the substituent effect. To this end, Ou and co-workers analyzed flavonoids by dividing them into three chemical classes. As the biological parameter, all these three classes of compounds were assayed for five cancer cell lines. The analysis of this work is shown in Table 2 [8].

This theoretical model has taken in account the cytotoxicity for cancer cells k562. After structural optimization and conformational analysis, a CoMFA analysis was determined. The initial PLS analyses were performed using the LOO cross-validation with the optimum number of components set as default.

The model with a best cross-validated $r_{c v}^{2}$, an optimum number of components determined by LOO method was used in a non-cross-validated analysis. The CoMFA model from LOO PLS analysis with 4 optimum components showed that for a non-cross-validated analysis an $\mathrm{R}^{2}$ of 0.897 , an estimated standard error is of 0.286 [8].

From this study, it was identified 5,7-dimethoxy flavonoids as the most potent anticancer agents than other two ana$\log$ series. This model provided evidences for using 5,7dimethoxy flavonoids as anticancer drug prototypes, since they are more promising than the other two chemical series [8].

$\mathrm{P}-\mathrm{gp}$ is a super-family of trans-membrane glycoproteins found in various resistant tumor cells, and responsible for the influx of anticancer agents from the nucleus to the cytoplasm, answering for the emergence of drug resistance $[35,36]$. The identification of flavonoids endowed with inhibitory properties for P-gp is worthy. In view of this, 42 compounds (see Table 3), purchased from the literature were assayed as antagonists of P-gp. As a biological parameter, $\mathrm{Kd}$ was measured and converted into $\mathrm{pK}_{\mathrm{d}}\left(-\log \mathrm{K}_{\mathrm{d}}\right)$ in order to use the data as a dependent variable in the CoMFA $\left(\mathrm{q}^{2}=0.747, \mathrm{Q}^{2}=0.639, \mathrm{r}_{\text {pred }}^{2}=0.802\right)$ and CoMSIA models $\left(\mathrm{q}^{2}=0.810, \mathrm{Q}^{2}=0.676, \mathrm{r}_{\text {pred }}^{2}=0.785\right)[26]$.

PIM-1 kinase is also an important cancer drug target for flavonoids. It is found in many cancer cell lines and is associated to the pathology outcome of lymphomas, leukemias, and prostate [28]. The identification of flavonoids inhibiting this kinase is an appealing line of research.

In the light of this, Holder and co-workers tested 15 flavonoids as PIM-1 inhibitors, using a CoMFA model to explain the biological results. The training series $(n=15)$ led to a non-cross-validated $\mathrm{q}^{2}=0.805$, a standard error of estimate of $0.376, F$ value $=24.79$, while the test set $(n=6)$ led to a $\mathrm{q}^{2}=0.825$. The calculated model showed to be a robust and reliable way to explain and predict the structural design of small-molecule PIM-1 kinase inhibitors [37].

\subsection{D versus $2 \mathrm{D}$}

Pick and co-workers compared 2D and 3D QSAR models for 28 flavonoids inhibiting the BCPR. (Fig. 6 and Table 4) summarize this chemical library [20].

Lipophilicity, calculated as either $\log \mathrm{P}$ or $\log \mathrm{D}$, has been used as a predictor for inhibition of BCRP flavonoids and analogues $[17,18]$. To analyze the substituent effect for the BCRP activity, a QSAR 2D analysis was calculated using the Free-Wilson method. On the other hand 3D QSAR analyses applying the CoMFA and CoMSIA methodologies

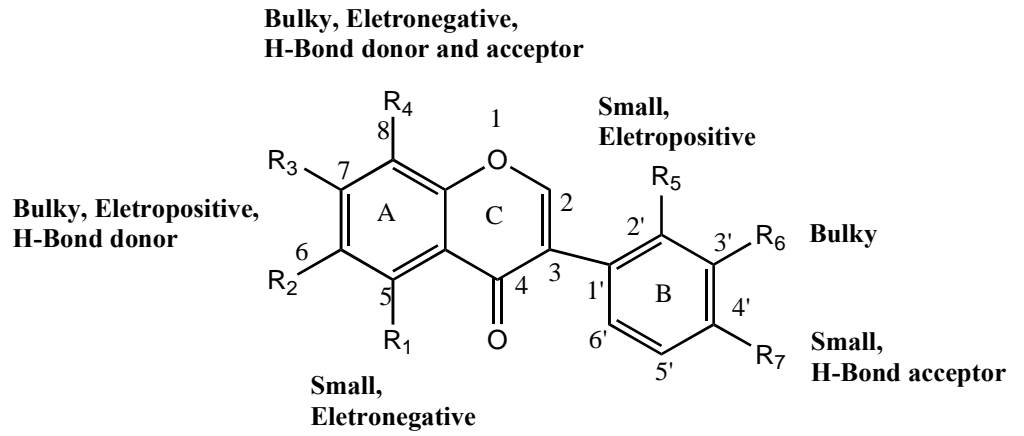

Fig. (5). Information from CoMSIA and CoMFA in regard to anticancer activity in colorectal cells of isoflavone variants. 
Table 2. Three Series used by Ou et al., 2011 and theirs Cytotoxic Activities Against Cancer Cell Lines In Vitro [8].

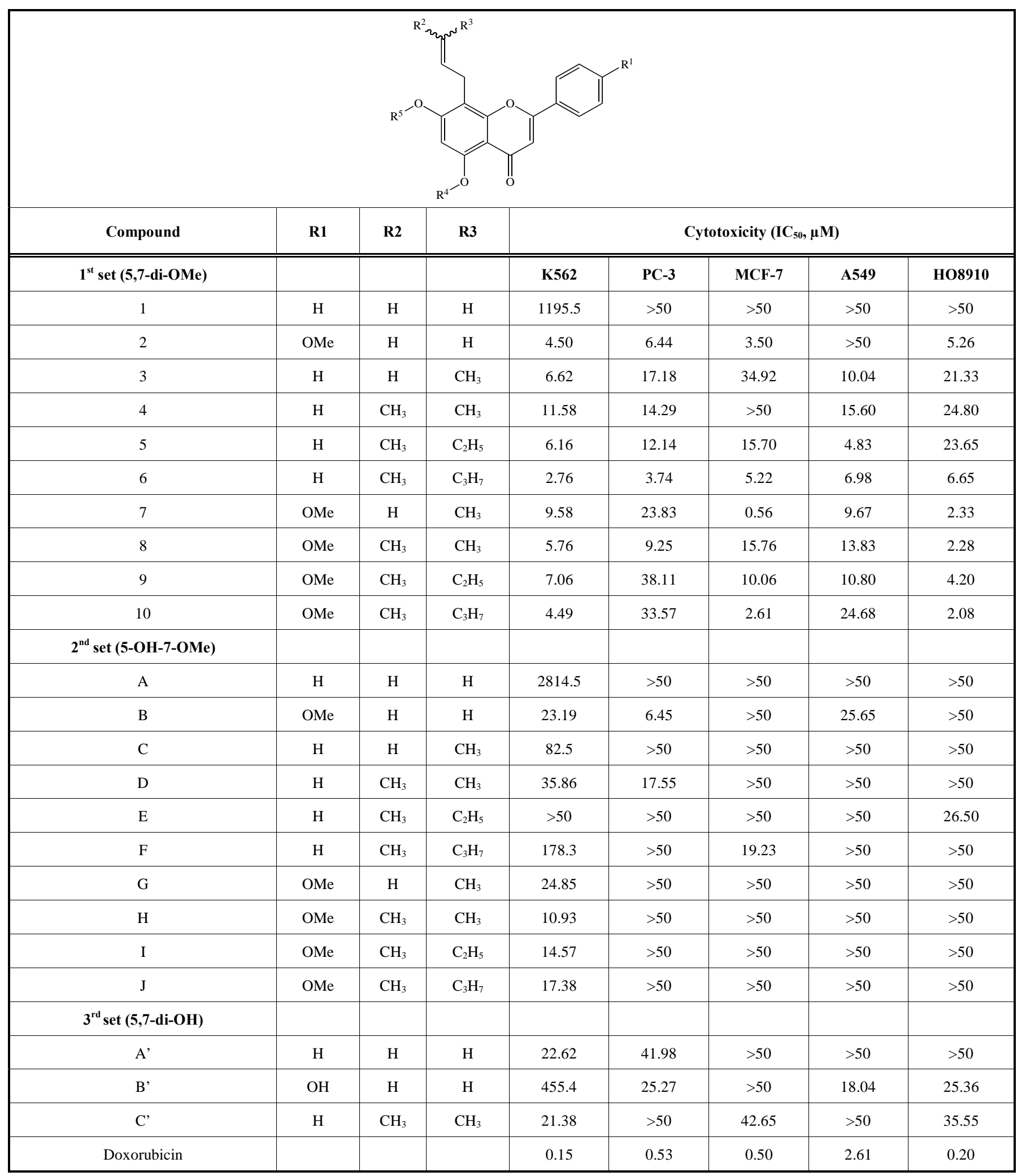

were performed to understand the molecular fields that describe the differences in inhibitory potency. The CoMSIA approach the highest $\mathrm{q}^{2}$ was obtained for the combination of electrostatic and hydrogen bond acceptor field $\left(q^{2}=0.624\right)$ and the best model using CoMFA using combined hydrogen bonding and electrostatic showed $\mathrm{q}^{2}=0.619$. The reliability of these two models was validated by LOO, LMO method and the scrambling stability test. When performing LMO $[38,39]$ the dataset was divided into several groups of equal size of the compounds were included in model generation 
Table 3. Structures and Activity used by Kothandan and Colleagues (2011) [35].

\begin{tabular}{|c|c|c|c|c|c|c|c|c|c|}
\hline & & Dipheny & hromen-4-o & 8 & & & & & \\
\hline $1^{\mathrm{a}}$ & $\mathrm{OH}$ & $\mathrm{H}$ & $\mathrm{H}$ & $\mathrm{H}$ & $\mathrm{H}$ & $\mathrm{H}$ & $\mathrm{H}$ & $\mathrm{H}$ & 5.00 \\
\hline 2 & $\mathrm{OH}$ & $\mathrm{OH}$ & $\mathrm{H}$ & $\mathrm{OH}$ & $\mathrm{H}$ & $\mathrm{H}$ & $\mathrm{H}$ & $\mathrm{H}$ & 5.23 \\
\hline 3 & $\mathrm{OH}$ & $\mathrm{OH}$ & $\mathrm{H}$ & $\mathrm{OH}$ & DMA & $\mathrm{H}$ & $\mathrm{H}$ & $\mathrm{H}$ & 6.35 \\
\hline 6 & $\mathrm{OH}$ & $\mathrm{OH}$ & $\mathrm{H}$ & $\mathrm{OH}$ & $\mathrm{H}$ & $\mathrm{H}$ & $\mathrm{H}$ & $\mathrm{OH}$ & 5.17 \\
\hline 7 & $\mathrm{OH}$ & $\mathrm{OH}$ & $\mathrm{H}$ & $\mathrm{OH}$ & $\mathrm{H}$ & $\mathrm{H}$ & $\mathrm{H}$ & $\mathrm{OCH}_{3}$ & 5.35 \\
\hline 8 & $\mathrm{OH}$ & $\mathrm{OH}$ & $\mathrm{H}$ & $\mathrm{OH}$ & DMA & $\mathrm{H}$ & $\mathrm{H}$ & $\mathrm{OCH}_{3}$ & 6.70 \\
\hline 9 & $\mathrm{OH}$ & $\mathrm{OH}$ & $\mathrm{H}$ & $\mathrm{OH}$ & $\mathrm{H}$ & $\mathrm{H}$ & $\mathrm{H}$ & $\mathrm{F}$ & 5.17 \\
\hline 10 & $\mathrm{OH}$ & $\mathrm{OH}$ & $\mathrm{H}$ & $\mathrm{OH}$ & $\mathrm{H}$ & $\mathrm{Cl}$ & $\mathrm{H}$ & $\mathrm{Cl}$ & 5.40 \\
\hline $11^{\mathrm{a}}$ & $\mathrm{OH}$ & $\mathrm{OH}$ & $\mathrm{H}$ & $\mathrm{OH}$ & $\mathrm{H}$ & $\mathrm{H}$ & $\mathrm{H}$ & I & 5.96 \\
\hline 12 & $\mathrm{OH}$ & $\mathrm{OH}$ & $\mathrm{H}$ & $\mathrm{OH}$ & $\mathrm{H}$ & $\mathrm{H}$ & $\mathrm{H}$ & $\mathrm{H}$ & 5.70 \\
\hline 13 & $\mathrm{OH}$ & $\mathrm{OH}$ & $\mathrm{H}$ & $\mathrm{OH}$ & $\mathrm{H}$ & $\mathrm{H}$ & $\mathrm{H}$ & $\mathrm{C}_{8} \mathrm{H}_{17}$ & 7.24 \\
\hline $18^{\mathrm{a}}$ & $\mathrm{H}$ & $\mathrm{H}$ & $\mathrm{H}$ & $\mathrm{H}$ & $\mathrm{H}$ & $\mathrm{H}$ & $\mathrm{H}$ & $\mathrm{H}$ & 4.47 \\
\hline 19 & $\mathrm{H}$ & $\mathrm{H}$ & $\mathrm{H}$ & $\mathrm{OH}$ & $\mathrm{H}$ & $\mathrm{H}$ & $\mathrm{H}$ & $\mathrm{H}$ & 4.46 \\
\hline 20 & $\mathrm{OH}$ & $\mathrm{H}$ & $\mathrm{H}$ & $\mathrm{H}$ & $\mathrm{H}$ & $\mathrm{H}$ & $\mathrm{H}$ & $\mathrm{H}$ & 5.00 \\
\hline $21^{a}$ & $\mathrm{H}$ & $\mathrm{OH}$ & $\mathrm{H}$ & $\mathrm{OH}$ & $\mathrm{H}$ & $\mathrm{H}$ & $\mathrm{H}$ & $\mathrm{H}$ & 5.05 \\
\hline 22 & $\mathrm{H}$ & $\mathrm{OH}$ & $\mathrm{CH}_{3}$ & $\mathrm{OH}$ & $\mathrm{H}$ & $\mathrm{H}$ & $\mathrm{H}$ & $\mathrm{H}$ & 5.51 \\
\hline 23 & $\mathrm{H}$ & $\mathrm{OH}$ & $\mathrm{H}$ & $\mathrm{OCH}_{3}$ & $\mathrm{H}$ & $\mathrm{H}$ & $\mathrm{H}$ & $\mathrm{H}$ & 5.20 \\
\hline 24 & $\mathrm{H}$ & $\mathrm{OH}$ & $\mathrm{CH}_{3}$ & $\mathrm{OCH}_{3}$ & $\mathrm{H}$ & $\mathrm{H}$ & $\mathrm{H}$ & $\mathrm{H}$ & 5.89 \\
\hline $25^{\mathrm{a}}$ & $\mathrm{H}$ & $\mathrm{OH}$ & $\mathrm{H}$ & $\mathrm{OH}$ & $\mathrm{H}$ & $\mathrm{H}$ & $\mathrm{H}$ & $\mathrm{OH}$ & 5.00 \\
\hline 26 & $\mathrm{H}$ & $\mathrm{OH}$ & $\mathrm{H}$ & $\mathrm{OH}$ & $\mathrm{H}$ & $\mathrm{H}$ & $\mathrm{F}$ & $\mathrm{F}$ & 5.20 \\
\hline 27 & $\mathrm{H}$ & $\mathrm{OH}$ & $\mathrm{H}$ & $\mathrm{OH}$ & $\mathrm{H}$ & $\mathrm{H}$ & $\mathrm{H}$ & I & 5.66 \\
\hline 28 & $\mathrm{H}$ & $\mathrm{OH}$ & $\mathrm{H}$ & $\mathrm{O}-\mathrm{iPr}$ & $\mathrm{H}$ & $\mathrm{H}$ & $\mathrm{H}$ & $\mathrm{H}$ & 6.00 \\
\hline 29 & $\mathrm{H}$ & $\mathrm{OH}$ & $\mathrm{iPr}$ & $\mathrm{OH}$ & $\mathrm{H}$ & $\mathrm{H}$ & $\mathrm{H}$ & $\mathrm{H}$ & 6.68 \\
\hline 30 & $\mathrm{H}$ & $\mathrm{OH}$ & $\mathrm{iPr}$ & $\mathrm{O}-\mathrm{iPr}$ & $\mathrm{H}$ & $\mathrm{H}$ & $\mathrm{H}$ & $\mathrm{H}$ & 6.55 \\
\hline $31^{\mathrm{a}}$ & $\mathrm{H}$ & $\mathrm{OH}$ & $\mathrm{iPr}$ & $\mathrm{O}-\mathrm{iPr}$ & $\mathrm{iPr}$ & $\mathrm{H}$ & $\mathrm{H}$ & $\mathrm{H}$ & 7.48 \\
\hline
\end{tabular}


(Table 3) contd....

\begin{tabular}{|c|c|c|c|c|c|c|c|c|c|}
\hline 32 & $\mathrm{H}$ & $\mathrm{OH}$ & $\mathrm{Bn}$ & $\mathrm{OH}$ & $\mathrm{H}$ & $\mathrm{H}$ & $\mathrm{H}$ & $\mathrm{H}$ & 6.47 \\
\hline 34 & $\mathrm{H}$ & $\mathrm{OH}$ & $\mathrm{Bn}$ & $\mathrm{OH}$ & $\mathrm{Bn}$ & $\mathrm{H}$ & $\mathrm{H}$ & $\mathrm{H}$ & 7.44 \\
\hline 35 & $\mathrm{H}$ & $\mathrm{OH}$ & $\mathrm{H}$ & $\mathrm{OBn}$ & $\mathrm{H}$ & $\mathrm{H}$ & $\mathrm{H}$ & $\mathrm{H}$ & 7.17 \\
\hline 37 & $\mathrm{H}$ & $\mathrm{OH}$ & $\mathrm{H}$ & $\mathrm{OH}$ & DMA & $\mathrm{H}$ & $\mathrm{H}$ & $\mathrm{H}$ & 6.70 \\
\hline 38 & $\mathrm{H}$ & $\mathrm{OH}$ & $\mathrm{H}$ & $\mathrm{OH}$ & Prenyl & $\mathrm{H}$ & $\mathrm{H}$ & $\mathrm{H}$ & 6.55 \\
\hline 39 & $\mathrm{H}$ & $\mathrm{OH}$ & Prenyl & $\mathrm{OH}$ & Prenyl & $\mathrm{H}$ & $\mathrm{H}$ & $\mathrm{H}$ & 7.82 \\
\hline
\end{tabular}

a - test set.

while the inhibitory potencies of the remaining substances were predicted. As the groups were randomly generated, this procedure was repeated 100 times to exclude the possibility of chance correlations and to validate the models. Results from the internal validation techniques, LMO, and scrambling stability test have pointed out the validity and robustness of the models. Contour plots were generated to visualize the contribution of the different substituents to the biological activity of the investigated compounds. The Fig. (7) summarizes the main structural features that affect the inhibition of BCRP by flavonoids [20].

\subsection{MLR}

As can be seen from a QSAR model derived from the stepwise multiple linear regression, electron transfer and the stability of the corresponding phenoxyl radicals resulting from $\mathrm{H}$-abstraction are important roles for the radical reaction. An analysis of these QSAR models for flavonoids and variants, clustered according to the antioxidant properties (i.e., potency)versus quantum parameters, provided information regarding to the electronic and energetic nature [12,14,16,21,40-43]. Among these parameters, the most important ones are:

- $\Delta \mathrm{H}_{\mathrm{f}}$, difference of enthalpy energy between the closed shell (phenolic) and radical (abstraction of the hydrogen) species;

- $\Delta \mathrm{H}_{\mathrm{OX}}$, energy activation of the intermediate cation radical, calculated by the difference between Hf_fc and Hf_fn, and also defined as the electron transfer enthalpy;

- $\mathrm{E}_{\mathrm{HOMO}}$, energy of the highest occupied molecular orbital, a parameter related to the electron-donating capacity of the molecule;

- $\mathrm{E}_{\mathrm{LuMO}}$, energy of lowest orbital molecular, a parameter related to the electron-donating capacity of the molecule;

- $\mathrm{H}-\mathrm{L}_{\mathrm{gap}}$, chemical hardness obtained by the difference of energy between orbital HOMO and LUMO.
Singh et al., 2009 [44] determined a QSAR for 32 oximeand methyloxime-containing flavones and isoflavones by MLR. To build the [45]. QSAR model, Singh and co-authors used the antiproliferative property for hepatocellular carcinoma SK Hep1 cells as a dependent variable. Fig. (8) shows the chemical structure of these compounds.

To this end, 122 descriptors were calculated in the VLife 2.0 program, including: $\mathrm{XcD}$ (X comp dipole), QMDMg (QM Dipole Magnitude) is the magnitude of the induced dipole moment. Internal validation was carried out by LOO method. These 32 compounds were divided in training (25 molecules) and test sets ( 7 molecules). The calculated equations were finalized and the multiple linear regressions were:

Equation 3

$\mathrm{pIC}_{50}=[13.618( \pm 3.691)+\mathrm{XcD}[0.097( \pm 0.0598)+\mathrm{SdOi}[-$ $0.909( \pm 0.293)] \pm \mathrm{QMDMg}[0.333( \pm 0.138)]$

$\mathrm{n}=25, \mathrm{r}=0.855, \mathrm{r}^{2}=0.730$, variance $=0.032, \mathrm{~s}=0.179$, $\mathrm{F}=18.977$, chance $<0.001, \mathrm{q}^{2}=0.605, \mathrm{~S}_{\text {press }}=0.217, \mathrm{SDEP}=$ 0.199 , Pred_r ${ }^{2}=0.300$.

Equation 4

$\mathrm{pIC}_{50}=[15.546( \pm 4.684)]+\mathrm{XcD}[0.099( \pm 0.072)]+\mathrm{DM}$ $[0.077( \pm 0.045)]+$ SdOi $[-1.050( \pm 0.373)]$

$\mathrm{n}=25, \mathrm{r}=0.805, \mathrm{r}^{2}=0.648$, variance $=0.052, \mathrm{~s}=0.229$ $\mathrm{F}=12.885$, chance $<0.001, \mathrm{q}^{2}=0.512, \mathrm{~S}_{\text {press }}=0.269, \mathrm{SDEP}=$ 0.247, Pred_r ${ }^{2}=0.577$.

It was interesting to note that various flavones and isoflavones, especially for the flavone-6-yl derivatives, had greater antiproliferative activity. Once QSAR predicted this, a second generation of flavone-6-yl variants with improved potency was designed. In fact, the predicted compounds were more potent than the initial ones [44].

An analysis of regression associated to the genetic algorithm for a series of 25 flavonoids, as inhibitors of BCRP, was determined by Zhang and co-workers. 115 structural 
<smiles>O=C1CC(c2ccccc2)Oc2ccccc21</smiles><smiles>O=c1cc(-c2ccc(O)cc2)oc2cc(O[C@@H]3O[C@H](CO)[C@@H](O)[C@H](O)[C@H]3O)cc(O)c12</smiles>

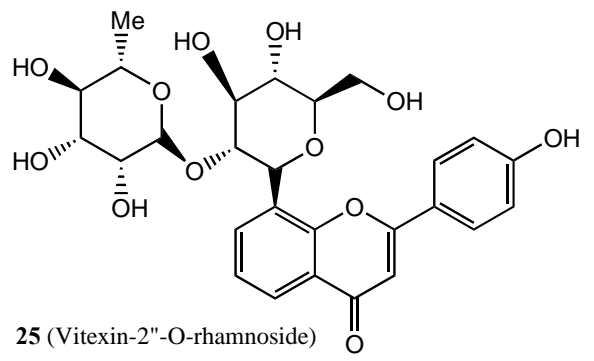

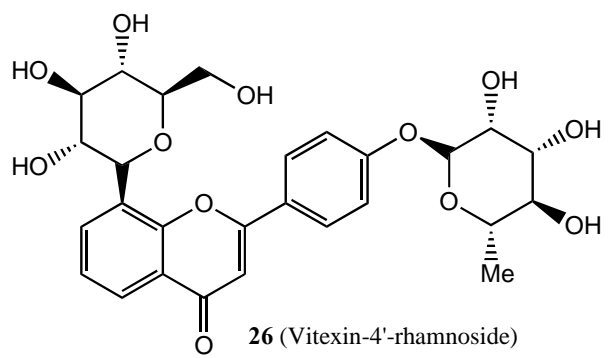<smiles>O=c1c(C[C@@H]2O[C@H](CO)[C@@H](O)[C@H](O)[C@H]2O)c(-c2ccc(O)c(O)c2)oc2cc(O)cc(O)c12</smiles><smiles>O=c1c(-c2ccc(O)cc2)coc2cc(O)cc(O)c12</smiles>

28 (Genistein)<smiles>COC1=C(OC)[C@]2(O)c3c(OC)c(OC)c4c(c3O[C@]23OC(c2ccccc2)=CC=C3C1=O)[C@H](O)C[C@@H](c1ccccc1)O4</smiles>

29 (Neocalycopteron)

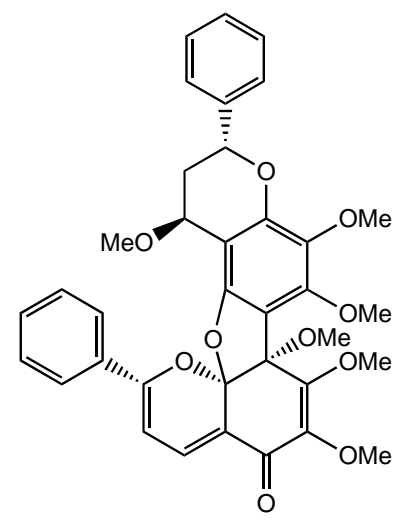

30 (Neocalycopteron-4-methylether)

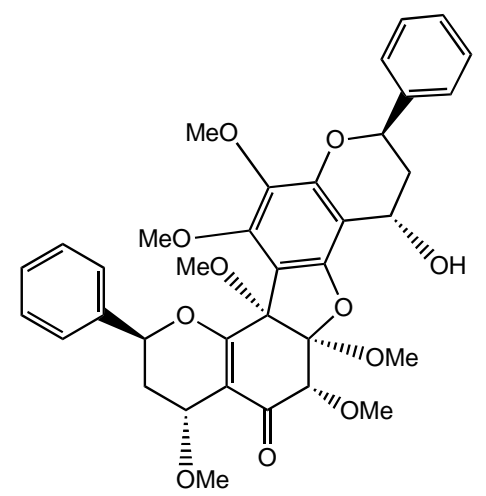

31 (Calyflorenon B)

Fig. (6). Chemical structures of the flavonoids used by Pick et al., 2011.

descriptors were determined from the QSARIS 1.2 software, such as: Kappa shape indices, electrotopological state indices, information indices, subgraph count indices, molecular polarizability, molecular weight, volume. The fitness function was defined as 1/LOF, LOF representing the Friedman's lack [17].

The best model is represented in the equation 5 .

Equation 5

$\mathrm{pEC}_{50}=1.156 \times \log \mathrm{P}+0.891 \times$ SdssC_acnt $-0.176 \times \mathrm{Dy}$ $+0.480$

$$
\left(R^{2}=0.852, Q^{2}=0.784\right)
$$

The $R_{\text {ext }}$ value was of 0.922 , indicating that the constructed model is valid and comparable with the build models with QSAR-3D and CoMFA. A positive contribution of $\log \mathrm{P}$ was observed for this model. As a result, the gain of hydrophobicity increases the inhibitory activity for BCRP when substituents were attached in the positions $6,7,8$ e 4' [17].

Using MLR and GA-PLS 50 flavonoid derivatives with p56lck protein tyrosine kinase inhibitory activity were studied [46]. Fassihi and collaborators observed the influence of substituent electronic descriptors (SED) parameters on protein tyrosine kinase inhibitory activity of the compounds. About 600 descriptors were generated: topological, geometrical, constitutional, functional group, electrostatic, quantum and chemical. The resultant GA-PLS model had a high statistical quality $\left(\mathrm{R}^{2}=0.74\right.$ and $\left.\mathrm{Q}^{2}=0.61\right)$ for predicting the activity of the inhibitors.

\subsection{MIF}

Many predictive models have been built, most of them using descriptors using MIFs. These descriptors are 
Table 4. Set and Activity of Flavonoids used by Pick et al., 2011 [20].

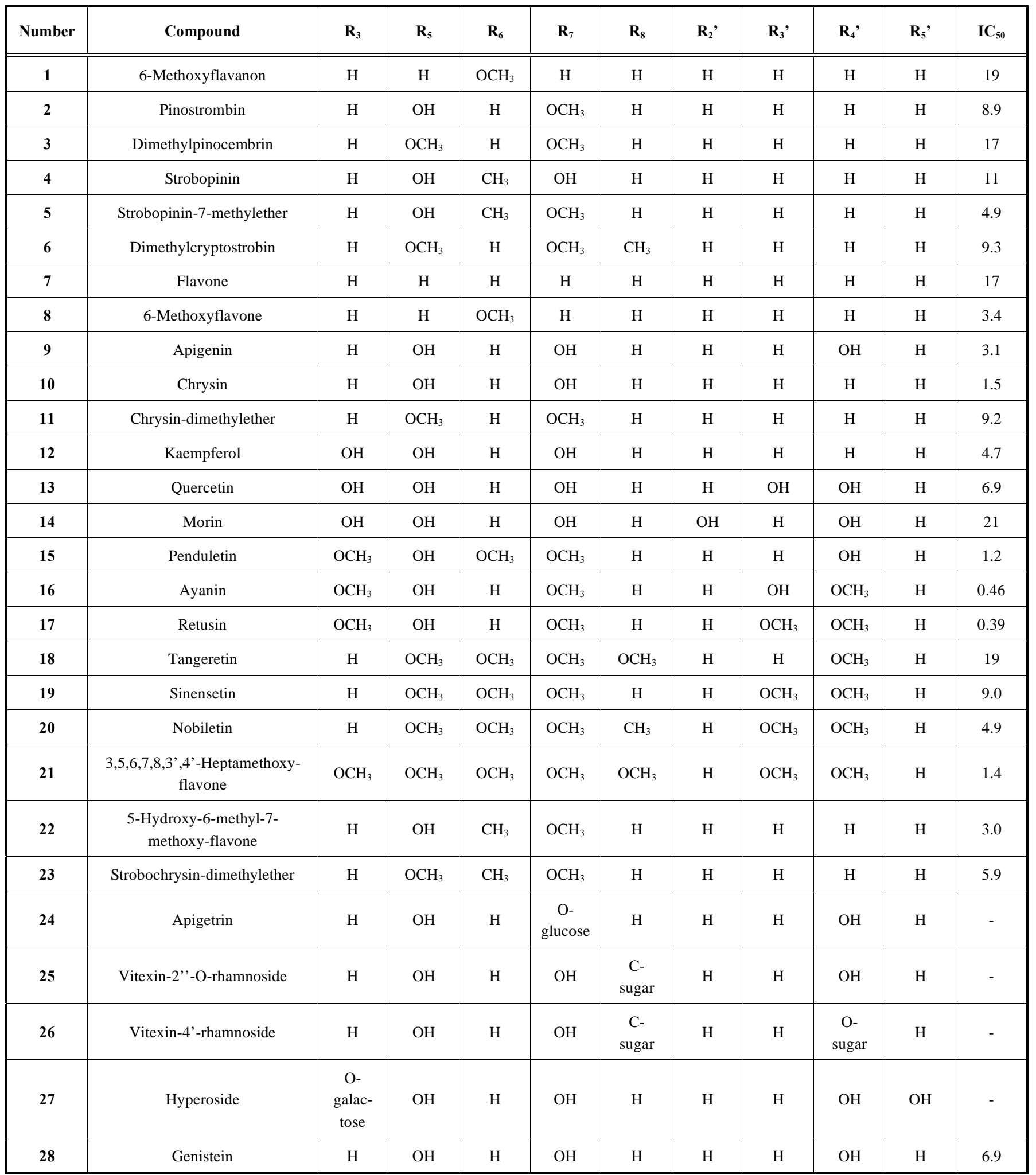

appropriated for correlating the tridimensional 3D interactions between the molecule and receptor [47, 48].

The inhibitory activity ABCG2/BCRP was investigated by VolSurf descriptors [49-51] of MIFs. To this end, a library of 34 flavonoids and flavonoid derivatives including flavones, benzopyranes, benzofuranes, boeravinones and acridones were biologically assayed.

Once the geometry of compounds was optimized by MMFF94s dataset, acceptor and donor parts of MHBPac and MHBPdo and the MLPho were computed, using a SYBIL 
8.0. For each MIF, 16 shape descriptors were calculated with VolSurf [49].

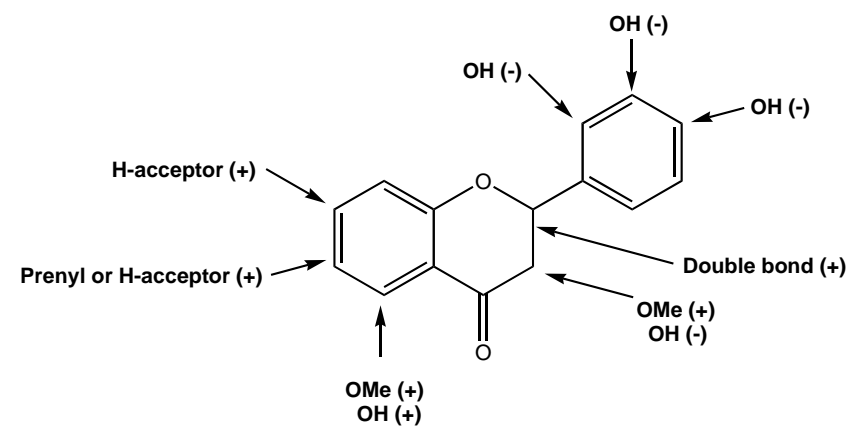

Fig. (7). Results are based on data from the 2D and the 3D QSAR approaches, where $(+)$ is the positive influence on inhibition of BCRP by flavonoids and (-) is the negative influence.

PCA and PLS analysis were performed with SIMCA-P 11.0. The models were evaluated by cross-validation using LOO method. The calculated model presented reliable robustness and statistical significance ( $\mathrm{r} 2=0.77 ; \mathrm{q} 2=0.70)$. Seven flavonoids were selected as external tests $\left(r^{2}=0.80\right)$. This QSAR-3D analysis ascertained the importance of molecular shape, polarizability and hydrophobicity of compounds for the inhibitory property [49].

\subsection{Neural Networks}

In another line, 57 flavonoids were purchased and assayed as inhibitors of P-gp [52]. Once the biological activity was ascertained, these compounds were submitted for BRNN, BPNN e PLS dataset methodologies. In this study, the biological activity (P-gp inhibition) was taken in account as the dependent variable. BRNN is a matrix based on a<smiles>[R2]O/N=C(\[R])COc1ccc2c(=O)c(-c3ccccc3)coc2c1</smiles>

probabilistic interpretation of network training to improve generalization ability of the classical neural networks. In contrast to conventional network training, the Bayesian approach involves a probability distribution of network weights. Classical BPNN is the widely common of the supervised learning models of neural network. Yet PLS expresses a dependent variable (target activity) in terms of linear combinations of the independent variables, commonly known as PCs [53-56].

(Table 5) sums the statistical index in regard to the three employed methods. In fact, the calculated model showed to be a reliable and robust in predicting flavonoids inhibiting $\mathrm{P}$ gp with improved affinity.

The calculated model showed to be a reliable and robust course in predicting flavonoids inhibiting P-gp with improved affinity.

\subsection{Others}

It has also been reported inhibitory activity of flavonoid derivatives for protein tyrosine kinase p561ck, a protein related to metastasis [57]. Some of 3D-QSAR studies analyze this activity using different methods.

One of these studies was conducted in 1998 by Nikolovska and collaborators. A set of 104 flavonoid derivatives were submitted on QSAR analysis using classical and quantum chemical parameters. The results showed that meta and para positions of the flavonoids (3' and 4') should have electron-donating properties to interact with the catalytic domain of the enzyme, through hydrogen bonds [58].

Zhou and collaborators used globally optimal CART (MPSOCART). The objective was formulated to decide the appropriate CART architecture and the optimum splitting<smiles>[R2]O/N=C(\[R])COc1ccc2c(=O)cc(-c3ccccc3)oc2c1</smiles>

Fig. (8). Structures of flavone and isoflavone derivatives used in QSAR method [35].

Table 5. Statistical Results of the Three Optimal QSAR Models for P-gp Flavonoid Inhibitors by Each Regression Method [52].

\begin{tabular}{|c|c|c|c|c|c|c|}
\hline \multirow{2}{*}{ Parameter } & \multicolumn{2}{|c|}{ BRNN } & \multicolumn{2}{c|}{ BPNN } & PLS \\
\hline & Training & Test & Training & Test & Training \\
\hline \hline Compounds & 43 & 14 & 43 & 14 & 43 \\
\hline PCs & 4 & 4 & 4 & 4 & 14 \\
\hline $\mathrm{R}^{2}$ & 0.756 & 0.728 & 0.826 & 0.679 & 0.392 & 0.655 \\
\hline $\mathrm{SEE}^{\mathrm{a}}$ & 0.120 & - & 0.119 & - & 0.657 & - \\
\hline $\mathrm{SEP}^{\mathrm{b}}$ & $-\mathrm{c}$ & 0.146 & - & 0.160 & - \\
\hline
\end{tabular}

a - standard error of estimate

$\mathrm{b}$ - standard error of prediction

c - not applicable or available 
parameters and the results were compared with PLS. MPSOCAT showed good power of prediction the bioactivities of flavonoid derivatives and inhibitory activities of inhibitors of epidermal growth factor receptor tyrosine kinase [59].

\section{DOCKING}

\subsection{Molecular Targets for Anticancer Flavonoids}

Molecular docking is defined as the collision of the substrate with the binding site in the correct conformation and orientation; therefore it can provide information about the stereochemical organization of the receptor binding site [60]. This method has been applied for anticancer flavonoids [61]. Among the proteins involved with the anticancer flavonoids, we can cite: aromatases, fatty acid synthases, xanthine oxidases, cyclooxygenases, lipoxygenases, ornithine decarboxylases, tyrosine kinases, and phosphoinositide 3-kinases.

\subsection{The Cytochrome P450 and the Anticancer Flavon- oids}

In the past decade, molecular docking between flavonoids and the cytochrome P450 family of enzymes was largely studied using natural products.

Enzymes of cytochrome P450 play many roles in the biosynthesis of essential molecular signal mediators, such as: steroid hormones, cholesterol, fatty acids, bile acids, as well as metabolize exogenous substrates (drugs and toxins). As a result, these enzymes are molecular targets for anticancer drugs. These enzymes also mediate the metabolic activation of innumerous carcinogens and participate of the inactivation / activation of anticancer drugs [62].

In view of this, Paoletta and co-workers [63] conducted a study of virtual screening of natural products gathered from 240 plants of the traditional Chinese Medicine (Chinese Herbal Constituents Database, CHCD) [64]. As a result of this massive virtual screening, a large number of compounds were identified as potential inhibitors of the human aromatase (CYP19), which catalyzes the aromatization reaction in cells and crucial within the estrogen biosynthesis. CYP19 is a promising molecular target for hormonal-dependent breast cancer therapy $[65,66]$, and thus the identification of natural products useful for inhibit this enzyme is a task that is receiving much attention.
Mammary carcinomas can be treated with the use of antiestrogens, which interfere with the binding of estrogen to its receptor. Another possibility is the treatment with aromatase inhibitors, which decrease the serum levels of estrogen by blocking the biosynthesis of the androgens into estrogen [67].

In light of this, to prospect for novel aromatase inhibitors, were calculated 238 different structural descriptors for these compounds: 150 2D (two dimensional), MOE descriptors (Chemical Computing Group, Montreal, Quebec), 56 KierHall descriptors [68] and 32 Labute VSA descriptors [69]. The structural features of 44 phytochemicals with known aromatase activity were used in the training Random Forest (RF) models to distinguish aromatase inhibitors in 8264 constituents used in the traditional Chinese medicine (TCM). The Random Forest model selected 30 compounds of what 22 compounds did not have been tested as aromatase inhibitors, and three compounds; denoted liquiritigenin, gossypetin, and myricetin (Figure M1) were purchased from commercial sources and tested as aromatase inhibitors.

The construction of molecular models to explain these three compounds and the docking model of these ligands into the aromatase catalytic site were first determined using the HyperchemTM version 7 (HypercubeInc., Gainesville, FL). Atomic coordinates for the Homology-modeled structure of human aromatase were collected from the Protein Data Bank13 (1TQA) [70]. Other molecular docking studies were later on determined using the FlexX program [71] (BioSolveIT GmbH, Sankt Augustin, Germany). The protein residues involved in the catalytic site for each ligand were defined with reference to the ligand pose in the most stable of the HyperchemTM modeled complexes. The FlexX docking was in all cases employed without constraints, and using the default values for all adjustable control parameters.

The docking model indicated that all these compounds (myricetin, gossypetin and liquiritigenin - Fig. 9) bind and form stable complexes with the enzyme, which make senses with the observed inhibitory properties of these compounds for catalytic activity of human aromatase $\left(\mathrm{IC}_{50} \mathrm{~s}\right.$ of 10,11 and $0.34 \mu \mathrm{M}$, respectively). The ranked order of the activities for the three TCM compounds agrees with the predicted stability calculated by manual docking studies, but does not agree for the FlexX docking calculations.

Another docking model was determined for the interaction between CYP1B1, CYP1A1, and CYPA2 and 18

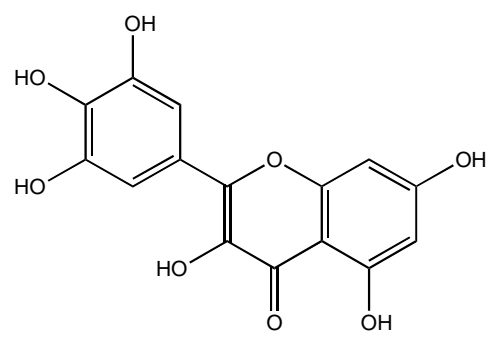

a

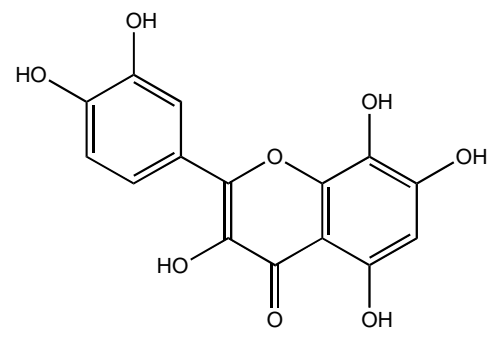

b

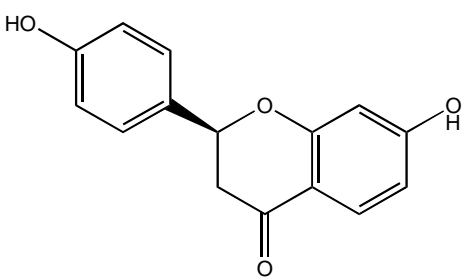

c

Fig. (9). Chemical structures of the potential aromatase inhibitors, (a) myricetin, (b) liquiritigenin and (c) gossypetin. 
methoxyflavonoids [72]. To this end, the Surflex Dock in SYBYL 8.0 (TriposInc., St. Louis, MO, USA) was employed. The CYP1B1 enzyme catalyzes the C4-position of E2 to 4-hydroxyestradiol (4-OHE2). 4-OHE2, but not 2OHE2, has a strong agonistic effect for the estrogen receptor (ER), and therefore is recognized to accelerate the proliferation of estrogen-dependent cells. CYPA1 is a key enzyme in the drug metabolizing pathway for the excretion of exogenous compounds absorbed into the body and CYP1A2 plays an important role in the detoxification of estrogen. CYP1B1, but not CYPA1 and CYPA2, is important for the estrogenrelated carcinogenesis, such as breast cancer [72].

The structures of CYP1A2 (PDB: 2HI4) and the CYP1A1 and CYP1B1 were constructed by sequence replacement using the SYBYL Biopolymer program (Tripos Inc., St. Louis, MO, USA) and the atomic coordinates (Arg34-Ser513) of the crystal structure of CYP1A2 (PDB; 2HI4) as a template [73].

The authors concluded that specific residues for each CYP1s, Thr-124 of CYP1A2, Ser-122 of CYP1A1 and Ala133 of CYP1B1, are crucial for these compounds inhibit the enzyme. These same authors also suggest that Ala-133 of CYP1B1 is important for the binding of methoxyflavonoids into catalytic site. The methoxyflavonoids, as isorhamnetin and chrysoeriol (Fig. 10), bind tight to the active site pocket of CYP1B1, but do not fit into the pockets of CYP1A1 and 1A2 because of collisions between both a methoxy substituent of these methoxyflavonoids and Ser-122 of CYP1A1 and Thr-124 of CYP1A2. These results explain why methoxyflavonoids with the 2-3 double bond in the C-ring can act as selective inhibitors against human CYP1B1 [72].

The dynamic and docking of chrysin (5,7-dihydroxyflavone - Fig. 11), a natural flavonoid extracted from many plants, honey, and propolis, for structures of CYP1A2 and its isoform CYP2C9, was determined in order to understand the selectivity of this compound [74].

Some researchers have also employed CDOCKER protocol implemented in the Accelrys Discovery Studio 2.1 [75] for the docking calculation. The ligand-binding site of 1A2 was defined and localized by using $\alpha$-naphthoflavone as a reference ligand. The authors selected the optimal pose based on both the docking energy and cluster popularity for further molecular simulation studies. Molecular dynamics simulation parameter files were prepared for each system using AMBER 10. The general AMBER force field (GAFF) was used as the parameters for ligands, while AMBER ff03 force field was used as the parameters for $1 \mathrm{~A} 2$ and $2 \mathrm{C} 9$.

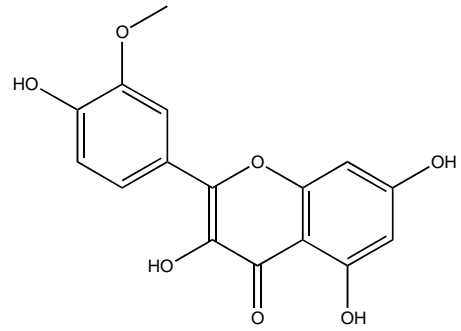<smiles>COc1cc(-c2cc(=O)c3c(O)cc(O)cc3o2)ccc1O</smiles>

b

Fig. (10). Chemical structures of the selective inhibitors of CYP1B1: (a) isorhamnetin and (b) chrysoeriol.<smiles>O=c1cc(-c2ccccc2)oc2ccccc12</smiles>

a<smiles>COc1ccc(-c2cc(=O)c3c(O)cc(O)cc3o2)cc1</smiles>

d<smiles>O=c1cc(-c2ccccc2)oc2cc(O)cc(O)c12</smiles><smiles>O=c1c(O)c(-c2ccccc2)oc2cc(O)cc(O)c12</smiles>

b<smiles>COc1ccc(-c2cc(=O)c3ccc(O)c(O)c3o2)cc1OC</smiles>

Fig. (11). Structures of six flavonoids used by Shimada and coworkers [76] in molecular docking simulations with CYP1A1, 1A2, 1B1, 2C9, 3 A4. 
The results showed that chrysin binds to $1 \mathrm{~A} 2$ in a similar model as $\alpha$-naphthoflavone (ANF) does, albeit with few differences. The authors have argued that larger binding site pocket of 2C9 may decrease the van der Waals' interactions with chrysin. Van der Waals' and electrostatic/H-bond interactions were the driving forces for its recognition of $1 \mathrm{~A} 2$. The predicted binding free energies using molecular dynamics for the 1A2-chrysin and 2C9-chrysin complexes were 23.11 and $-20.41 \mathrm{kcal} / \mathrm{mol}$, respectively, indicating that the chrysin was more potential for the binding with $1 \mathrm{~A} 2$. Weaker van de Waal's interactions between 2C9 and chrysin may be the reason for its moderate inhibitory affinity. The authors concluded that hydrophobic/van der Waals' interactions are a crucial element of binding for $1 \mathrm{~A} 2$. Because of the hydrophobic nature of chrysin, these interactions should play an important role in the binding of chrysin to $1 \mathrm{~A} 2$. The flavone ring of chrysin has conventional interactions with the $1 \mathrm{~A} 2$ residues [74].

Shimada and coworkers described the inhibition of human enzymes CYP1A1, 1A2, 1B1, 2C9 and 3A4 by 33 flavonoids and selected six to determine the docking poses [76]: five active inhibitors P450 enzymes: flavone, chrysin, galangin, acacetin, 5,7-dihydroxy-3',4'-dimethoxyflavone; and one inactive: 2-(3,4-dimethoxyphenyl)-7,8-dihydroxy4H-chromen-4-one one (Fig. 11).

The crystal structures of $1 \mathrm{~A} 2,2 \mathrm{C} 9$, and $3 \mathrm{~A} 4$ have recently been reported $[73,77,78]$. $1 \mathrm{~A} 1$ and $1 \mathrm{~B} 1$ primary sequences were aligned with human 1A2 (PDB Data Bank code 2HI4) in the MOE software (version 2009.10, Chemical Computing Group, Montreal, Canada) for modeling of a three dimensional structure. Prior to docking, the energy of the P450 structures was minimized using the CHARMM22 force field. Docking simulation was carried out for flavonoid binding to P450 enzymes using the MMFF94x force field distributed in the MOE Dock software. Twenty solutions were generated for each docking experiment and ranked according to total interaction energy.

This docking model argues that there are different mechanisms in the interaction of flavonoids with CYP1A1, $1 \mathrm{~A} 2$ and $1 \mathrm{~B} 1$. One of the mechanisms of inhibition of CYP1A2 suggested by the authors is because of the direct interaction of flavonoids with active site, although such mechanisms must be ruled out for CYP1A1 and 1B1 because of the observation of possible interaction of 2-(3,4dimethoxyphenyl)-7,8-dihydroxy-4H-chromen-4-one Figure M4 - b) one inactive, a weak inhibitor, with the active site these enzymes. The authors concluded that there are different orientations in the interaction of the six flavonoids with the five CYP enzymes examined and that two or more mechanisms are possible to explain how various flavonoids inhibit each single P450 enzymes in specific modes [76].

A study of a 14 dietary flavonoids with functional inhibitory properties for CYP1A1 and CYP1B1 were published and molecular docking simulations were employed with the aim to rationalize the activity of these flavonoids based on their CYP1-binding mode [79]. The authors used the software Modeller 9.4 [80] to generate the homology models of CYP1A1 and CYP1B1 using the crystallographic structures of CYP1A2 (PDB ID: 2HI4) [64] and CYP2C9 (PDB ID: 1R9O) [77] as templates. The 3D coordinates of the flavonoids were generated from their SMILES representation using the Omega 2.1 [81]. AutoDockTools1.5.4 was employed for the preparation of proteins and ligands with the united- atom approximation [82]. Docking calculations were performed using the AutoDock4.2 [83].

Androutsopoulo and coworkers discussed some docking results based on the 4 most active flavonoids: diosmetin, eupatorin, chrysin and acacetin (Fig. 12). The simulated binding orientation of the studied flavonoids was in accordance with the previously reported and cited in this review [72]. Molecular docking reveals favorable energies for polymethoxylated flavonoids, as eupatorin, with respect to binding orientations to the heme group, as opposed to polyhydroxylated flavonoids [79].

Bonfield and co-workers reported a recent study about the design and development of isoflavanone derivatives as potential aromatase (CYP19) inhibitors, based on isoflafone 3-phenylchroman-4-one (isoflavanone) derivatives [84]. Docking simulations were employed to investigate the interactions between enzyme and inhibitor, such as hydrophobic interactions, hydrogen bonding and heme iron coordination. The coordinates of the X-ray crystal structure of the aromatase (CYP19A1) androstenedione complex (PDB code 3EQM) were collected from the Protein Databank (http://www.rcsb.org) and imported into the modeling program SYBYL (version 8.0; Tripos, St. Louis, MO). Inhibitor structures were computationally docked into the enzyme's binding site using the program GOLD (version 5.0.1.; CCDC, Cambridge, UK), which operates with a genetic search algorithm and allows for complete ligand and partial binding site flexibility [85].

The obtained data showed good inhibitory potencies of isoflavanone derivatives against aromatase, revealing that the<smiles>COc1ccc(-c2cc(=O)c3c(O)c(OC)c(OC)cc3o2)cc1O</smiles>

a<smiles>O=c1cc(-c2ccccc2)oc2cc(O)cc(O)c12</smiles>

c<smiles>COc1ccc(-c2cc(=O)c3c(O)cc(O)cc3o2)cc1</smiles>

d

Fig. (12). Structures of a) diosmetin, b) eupatorin, c) chrysin and d) acacetin. 
<smiles>O=C1c2ccccc2OCC1c1ccccc1</smiles><smiles>COc1ccc2c(c1)C(=O)C(c1ccccc1)CO2</smiles>

$\mathrm{b}$<smiles>COc1cc(OC)cc(C2COc3ccccc3C2=O)c1</smiles>

c<smiles>O=C1c2ccccc2OCC1c1cccnc1</smiles>

d

Fig. (13). Structures of isoflavones derivatives used with inhibitory activity against CYP19A1 [84].

non-planarity configuration of the isoflavanone scaffold might be the reason for the enzyme-ligand binding. Specifically, compound 6-methoxy-3-phenylchroman-4-one bearing a methoxy group at $\mathrm{C} 6$ position came out as the most potent inhibitor, with a 100-fold potency enhancement in comparison to the isoflavanone (Fig. 13). The authors identified most the structural features that enable isoflavanones bind to the aromatase active site with high affinity: Isoflavanone rings $\mathrm{A}$ or B may participate in $\pi-\pi$ stacking interactions with aromatase's porphyrin ring or amino acid residues, such as Phe 221, Trp224 and Phe 134. Moreover, the same authors argued that the methoxy groups, that are present in 6-Methoxy3-phenylchroman-4-one and 3-(3,5Dimethoxyphenyl)chroman-4-one (Fig. 13), increase the binding affinity because of hydrogen bonds with aromatase residues, such as Met 374, Arg 192 and Ser 478. Heterocyclic nitrogen (3-(Pyridin-3-yl)chroman-4-one, Fig. 13) or carbonyl oxygen atom of the inhibitors coordinates towards the heme iron atom, thereby enhancing the binding interactions [84].

Another study reported in the same year [86], used the same pdb structure X-ray crystal structure of aromatase enzyme reported by [87] (PDB ID: 3EQM) for 39 compounds belonging to flavone, flavanone, and structural derivatives of the isoflavone. Three molecular docking programs used in this study were GOLD v4.0 (Cambridge Crystallographic Data Centre, Cambridge, 2000 UK.), LIGANDFIT (Discovery Studio Modeling Environment Release 2.1, 2008, San Diego, USA: Accelrys Software Inc) and GLIDE v5.5. The prediction models were generated using stepwise multiple linear regression method to correlate the $\mathrm{pIC}_{50}$ values to docking descriptors and scores. Results showed that these analogues bind in a similar mode and the calculated $\mathrm{pIC}_{50}$ values demonstrate significant linear correlation, with internal cross-validation (leave-one-out) prediction coefficient (q$\left.{ }_{\text {loo }}^{2}>0.8\right)$, with the experimental aromatase inhibition.

The same research group of the prior cited work also determined a docking model for 6,8-dibromo-2-aryl-2,3dihydroquinolin-4(1H)-ones, which were evaluated in vitro (for MCF-7 breast cancer cell lines) [88]. The docking stud-

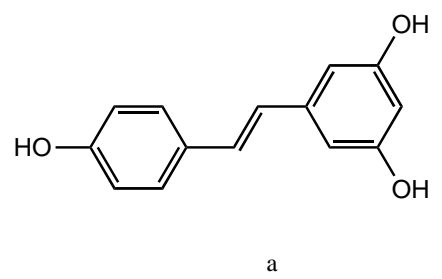

ies were determined to recognize the binding motif of the title compounds within the active of aromatase enzyme employing GOLD docking software using the same X-ray crystal structure of human placental microsomal aromatase (PDB ID: 3EQM) [78]. All the compounds were docked well into the active site of aromatase enzyme site and interacted with the cyclic ketone group with the heme of the aromatase. The most active compounds (Fig. 14) form a hydrogen bonding with Ser 478 or Asp 309 amino acids of the active site, which probably account, according the authors, for their better activity compared to other analogs of the series [88].

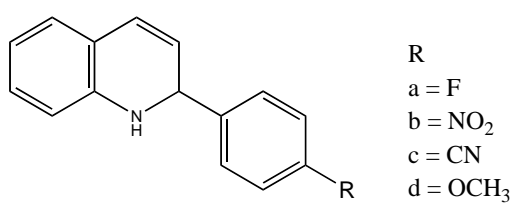

Fig. (14). Structures of 6,8-dibromo-2-aryl-2,3-dihydroquinolin4(1H)-ones with most inhibitory activity against CYP19A1.

\subsection{Kinase Inhibitors}

Protein kinases are known to play important roles within the cellular processes of division, proliferation, metabolism, and apoptosis. Up or down regulation of protein kinases have been found in chronic myelogenous leukemia, gastrointestinal stromal cancer, and various other sarcomas [89].

To ascertain the potential of flavonoids as lead compounds for cancer treatment as well as their role in cancer prevention, a large number of studies have been done using flavonoids as inhibitors of protein kinases. In this line of research, Lee and co-workers have compared resveratrol, a nonflavonoid compound and quercetin (Fig. 15), both present in red wine. Using an inhibitory vitro assay against Rapidly Accelerated Fibrosarcoma (Raf1) and mitogen-activated protein kinase/extracellular signal-regulated kinase kinase (MEK1), together with docking calculations, these authors have identified the mode of action of these anticancer compounds [90]. The extracellular signal-regulated kinase activa-

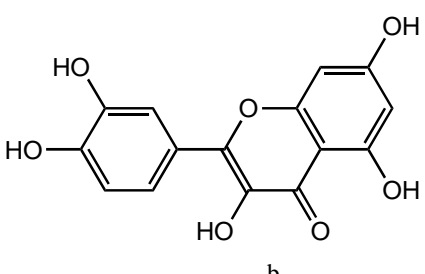

Fig. (15). Structures of resveratrol (a) and quercetin (b). 
tion (ERK) is shown in various types of tumors [91]. The down-regulation of ERK, through the inhibition of upstream kinases such as Raf or MEK, is a feasible way for intervening in carcinogenesis. The docking studies and structural analysis were performed using the computational program Insight II (Accelrys) with the crystal coordinates of MEK1 (accession code 1S9J), which are available in the Protein Data Bank. These authors concluded the binding mode of resveratrol is similar to that of quercetin. Moreover, the 3' position of resveratrol is located in the 3 ' position of quercetin. However, the absence of the hydroxyl group at the 3' position of resveratrol does not lead to the formation of a hydrogen bond between resveratrol and the backbone amide group of Ser212 [90].

The same authors calculated a docking model of kaempferol (figure $\mathrm{k} 3 \mathrm{-c}$ ), which is a natural dietary flavonoid and also a phosphatidylinositol 3-kinase (PI3K) inhibitor [92]. PI3K is the major signaling component responsible for the downstream of several growth factor receptor tyrosine kinases. As a result, PI3K inhibitors attenuate epidermal growth factor [92]. The same computational program, Insight II (Accelrys, San Diego, CA) was used for the docking calculations and the crystal coordinates of PI3K in complex with ATP or quercetin (accession numbers 1E8X and 1E8W) bonds were used. Based on the previous data that kaempferol is an adenosine triphosphate (ATP)-competitive inhibitor, the authors docked the compound into the adenosine triphosphate-binding site. The high-level inhibitory activity of kaempferol may be because of hydrogen bonds between the carbonyl group at position 4 and the hydroxyl groups at position 5 of the backbone of Val887 in the hinge region of PI3K.On the other hand, hydroxyl groups at positions 7' and 4' establish hydrogen bonds with the side-chains of Lys890 and Asp841, respectively, while the hydrophobic interaction with the side-chains of residues in the ATP-binding site [92].

Later on, these same authors reported another docking study suggesting kaempferol also inhibits UVB-induced cyclooxygenase- 2 expression by suppressing the Src kinase activity [93]. The Src tyrosine kinase is a member of a superfamily of membrane associated non-receptor tyrosine kinases, which were identified as proto-oncogene mediators [94].

The docking model was calculated using the program Insight II (Accelrys, San Diego, CA) and the crystal coordinates of Src (accession code 1YOJ). The docking model suggested that kaempferol indeed interacts with the backbone atoms in the hinge region of Src, as other protein kinase inhibitors do. The hydroxyl group at the 5-position and the carbonyl group at the 4-position of kaempferol forms two hydrogen bonds with the backbone atoms of Met343 in the hinge region of Src. The authors also suggested that hydroxyl groups at the 4' - and 7-positions of kaempferol might establish additional hydrogen bonds with Glu312 and Asp350, respectively. Yet the hydrophobic residues in the ATP-binding site, including Ala295, Ala405, Leu395, Val325, Leu275, and Val283 interact with the inhibitor [93].

Another interesting example is the glycogen synthase kinase-3b (GSK-3b). GSK-3b leads to a decrease in pancreatic cancer cell proliferation by abrogating the functional activity of nuclear factor $\mathrm{jB}(\mathrm{NFjB})$. In view of this, Johnson and co-workers tested flavonoids of citrus fruits [95] because of the previous epidemiologic knowledge that between the consumption of citrus fruits and decreased chances of pancreatic cancer occurrence. The in vitro studies conducted with flavonoids of these fruits inhibit the proliferation of human pancreatic cancer cells [96].

The chemical structures of most citrus compounds were collected from the Kyoto Encyclopedia of Genes and Genomes database (http://www.genome.jp/kegg/) and/or were built in the Molecular Operating Environment program. Therefore, the energy was minimized using the MMFF94 force-field. 38 ligands were docked into the active site of the minimized-energy configuration of GSK-3b protein and a model was calculated by using the DOCK function within the Molecular Operating Environment program. The docking model indicated the flavonoids stabilize the GSK-3b active site because of hydrogen bonding with the amino acid residues Lys85 and Arg141. Moreover, the authors identified that flavonoids containing a hydroxyl groups that are available for hydrogen bonding with the amino acid residues in the enzyme contribute to provide stability, while large side groups, as such methoxy groups or sugar conjugations, are less suitable in providing stability (Fig. 16) [95].

Another study aimed to identify the structural determinants and the pharmacological core for prenyl flavonoids as PKB/Akt1 inhibitors [97]. PKB/Akt, the serine/threonine proteases, which belongs to the AGC family of kinases are molecular targets for cancer therapy since they protect cancer cells of apoptosis, increase cancer growth and cancer resistance [98]. In light of these findings, researches employed 24 compounds to build pharmacophore models, and therefore a virtual screening of an in-house database was determined. These researches tested 9 hits for in vitro studies of enzyme inhibition. They also used several computational docking programs: FlexiDock (Molecular Modelling System, Tripos Associates: St. Louis, MO, USA.), FlexX [71], LigandFit [99], CDOCKER [75] and Libdock [100], and six PKB/Akt1 ligand complex (PDBcode: 3CQU, 3CQW, $3 \mathrm{MV} 5,3 \mathrm{MVH}, 3 \mathrm{OCB}$ and 3OW4) were retrieved from the Protein Data Bank (PDB, http://www.pdb.org). The flavonoids showed in Fig. (17) were the most potent inhibitors, with $\mathrm{IC}_{50}=5.4$ and $3.9 \mu \mathrm{M}$, and lowest docking energies: 3545.05 and $-3766.5 \mathrm{kcal} / \mathrm{mol}$, respectively [97].

The cyclin-dependent kinases (CDKs), each one with their respective regulatory cyclin, are involved in the regulation of the cell cycle, apoptosis, and transcription, these enzymes are thus interesting targets for cancer therapy [101].

Another in silico study was carried out to underlay the mode of action in terms of molecular dynamic as well as the binding affinity of fisetin, apigenin, and chrysin (Fig. 18) to the cyclin-dependent kinase 6/cyclin D. Complexes were calculated [102] using the Flexible Docking module in the Discovery Studio 2.5 (Accerys, Inc.).

The initial structure of the fisetin-CDK6/cycD complex was taken from the Protein Data Bank (1XO2). The docking energies followed the same order of inhibitory affinity (fisetin>apigenin>chrysin), being in a good agreement with the experimental $\mathrm{IC}_{50}$ values of $0.85,1.70$ and 6.0 respectively. Hydrogen bond formation and van der Waals interactions seem to be important for the binding of these three 
<smiles>O=c1cc(-c2ccc(O)c(O)c2)oc2cc(O)cc(O)c12</smiles><smiles>O=c1cc(-c2ccccc2)oc2ccccc12</smiles>

$\mathrm{e}$<smiles>COc1ccc(-c2cc(=O)c3c(OC)c(OC)c(OC)c(OC)c3o2)cc1</smiles><smiles>O=c1cc(-c2ccc(O)cc2)oc2cc(O)cc(O)c12</smiles>

b<smiles>CCc1cc(O)c2c(c1)OC(c1ccc(OC)c(O)c1)CC2=O</smiles><smiles>O=c1c(O)c(-c2ccc(O)c(O)c2)oc2cc(O)cc(O)c12</smiles>

c<smiles>O=c1c(O)c(-c2ccc(O)cc2)oc2cc(O)cc(O)c12</smiles>

d<smiles>COc1ccc(-c2cc(=O)c3c(OC)c(OC)c(OC)c(OC)c3o2)cc1OC</smiles>

g

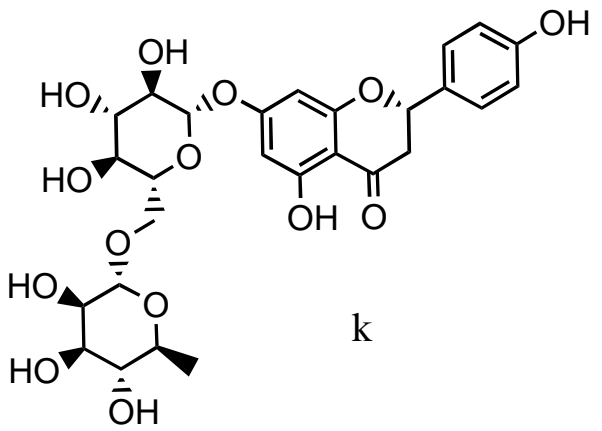

Fig. (16). Structures of luteolin (a), apigenin (b), quercetin (c), kaempferol (d), flavone (e), heseperetin (f), narigenin (g), nobiletin (h), tangeretin (i), rutin (j), narirutin $(k)$.<smiles>CC(C)=CCc1c(O)cc2oc(-c3ccc(O)c(O)c3)cc(=O)c2c1O</smiles><smiles>CC(C)=CCc1c(O)cc(O)c2c(=O)cc(-c3ccc(O)c(O)c3)oc12</smiles>

Fig. (17). Structures of potent prenylated flavonoids inhibitors of PKB/Akt1,(a) $\mathrm{IC}_{50}=5.4 \mu \mathrm{M}$, apigenin (b) $\mathrm{IC}_{50}=3.9 \mu \mathrm{M}$.<smiles>O=c1c(O)c(-c2ccc(O)c(O)c2)oc2cc(O)ccc12</smiles><smiles>O=c1cc(-c2ccc(O)cc2)oc2cc(O)cc(O)c12</smiles><smiles>O=c1cc(-c2ccccc2)oc2cc(O)cc(O)c12</smiles>

Fig. (18). Structures of (a) fisetin, (b) apigenin, and (c) chrysin with IC50 values of $0.85,1.70$ and 6.0 respectively against CDK6/cycD complex.

different flavonoids for the CDK6/cycD. However, the binding strength of the flavonoid depends on the number and location of the hydroxyl groups as well as their orientation in the ATP binding pocket. To clarify this, structural modifica- tions were performed in 7-position of the A ring of fisetin and the researchers observed that replacing it by a methyl amine group as well as the insertion of an acetamide group at the $4^{\prime}$-position on the B-ring are tolerated [102]. 
A virtual screening study using docking approach and an in-house flavonoids database containing 2,620 compounds, including aurones, chalcones, flavones, flavanones, isoflavones, biflavonoids, anthocyanidins, dihydrochalcones and proanthocyanidins were tested against the p90 ribosomal S6 kinase 2 (RSK2), a cancer-related protein [103]. The structure (PDB ID:3G51) was collected from the PDB Bank for virtual screening studies. The computational program GLIDE from the Schrodinger Suite 2011 was used for the docking simulations.

Quercentim and kaempferol (Fig. 15 and 16, respectively), were selected and their functional activity were confirmed using experimental assays. A docking simulation was performed using the flavonoid isorhamnetin and mitogenactivated protein kinase kinase 1 (MEK1) (PDB: 1S9J) and the results show that hydrogen bonds were formed between isorhamnetin (Fig. 19) and the backbone of MEK1, including Val127 located the ATP-noncompetitive binding site and Ser212 in the activation loop and hydrophobic interactions with the side chain at Ile99, Phe129, Ile141, Phe209 and Leu118 [103].

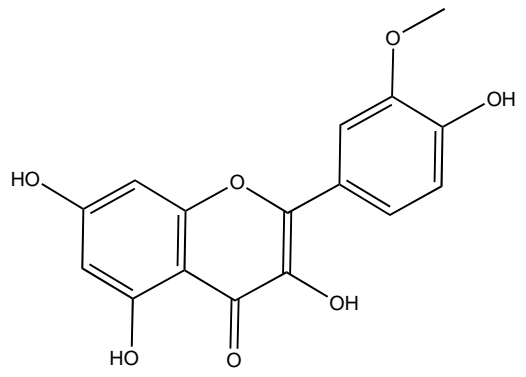

Fig. (19). Structure of flavonoid isorhamnetin.

\subsection{Others Targets and Multi-Target Studies}

Heat shock proteins (Hsps) are over-expressed proteins in human cancers. They are implicated to the cancer cell proliferation, differentiation, invasion, metastasis, death, and recognition by the immune system [104].

Because of these pharmacological importance, docking study between 18 flavonoids (flavones, flavonols, isoflavones, and flavanones) and the structure of the heat shock protein 90(HSP90) was studied in detail by using the computational program Ligandfit along to many other mathematical functions: Dockscore, PLP1, PLP2, and PMF [105]. The crystal structure of human Hsp90 receptor was collected from the Protein Data Bank (ID: 2BSM). From this work, it was interesting to note that the isoflavones led to high values of scores functions, but the docking poses of these compounds were not located to the ATP binding site of HSP90. The authors proposed that the phenyl ring on position 3 has a rigid structure so that isoflavones would only bind to the outer domain. Quercetin (Fig. 16) had the lowest interaction energy in our molecular simulation. By molecular simulation, luteolin (Fig. 16) showed the highest docking score of all tested flavonoids.

Using the computational program Autodock, involving another HSP protein, $70 \mathrm{kDa}$ heat-shock protein (Hsp70), that regulates apoptosis in cancer cells, and green tea flavonoid (+)-epigallocatechin 3-gallate (Fig. 20) which induces apoptosis in numerous cancer cell lines were performed [106]. Two pharmacophore maps, which reproduced the docking model, were determined based on the hydrogen bonding interactions and hydrophobic interactions. The scoring functions (LigScore2, PLP1, and PLP2) were calculated for hits to establish a relationship between this pharmacophore and the set of twenty three naturally-occurring flavonoids and ten catechin based polyphenolic flavonoids extracted from green and black tea inhibitors using Cerius2. Only two flavonoids: myricetin (Fig. 9) and (+)-gallocatechin -(GC - Fig. 20) were selected as potent inhibitors. Three hydroxyl group of B-ring in myricetin and gallo group of GC formed important hydrogen bonds, and 7-OH of A-ring in myricetin and $\mathrm{OH}$ group of catechin moiety in GC participated in hydrogen bonding interactions [106].

Some others structure approaches using docking and several types of enzymes that were cancer related were performed. Deschamps and co-workers a work [107] that use baicalein (Fig. 21) and apigenin (Fig. 18) and 15-human Lipoxygenase that is related to colorectal cancer [108]. 15hLO-1 homology model was created using the Protein Local Optimization Program. The software structures of apigenin (Fig. 18) and baicalein (Fig. 21) were prepared for docking using the LigPrep and computational program Glide to perform docking simulations. The authors verified that baicalein<smiles>O=C(O[C@H]1Cc2c(O)cc(O)cc2O[C@@H]1c1cc(O)c(O)c(O)c1)c1cc(O)c(O)c(O)c1</smiles><smiles>Oc1cc(O)c2c(c1)O[C@H](c1cc(O)c(O)c(O)c1)[C@H](O)C2</smiles>

a

Fig. (20). Structures of (a) (+)-epigallocatechin 3-gallate and (b) (+)-gallocatechin. 
is a redox inhibitor against $15-\mathrm{hLO}-1$, which most likely binds directly to the catalytic iron through its catechol moiety, while apigenin does not.

A set of 9 natural flavonoid compounds which possess a plane configuration of cis $\mathrm{C}-4$ ketone and C-5 hydroxy were submitted by molecular docking using AutoDock 3.0 [109]. The complex structure of human glyoxalase I (hGLO I), that is highly expressed in the most tumor cells and little in normal cells was obtained from the Protein Data Bank (PDB) (code 1FRO). The docking results show that hydroxyl groups at position 3', 4', 5' (ring B) and 6 (ring A), structural features present in baicalein (Fig. 21), luteolin, kaempferol, quercetin (Fig. 16) and myricetin (Fig. 9) have positive contribution to inhibitory activity.<smiles>O=c1cc(-c2ccccc2)oc2cc(O)c(O)c(O)c12</smiles>

Fig. (21). Structure of baicalein.

Apigenin (Fig. 16), tricin (Fig. 22) and $3^{\prime}, 4^{\prime}, 5,5,7-$ pentamethoxyflavone (PMF - Fig. 22) were docked into the indomethacin-bound structure of cyclogenase COX-2, considered to be important mechanisms of colorectal cancer chemoprevention, (PDB entry: 4COX; ref. 20) and the ibuprofen-bound structure of COX-1 (PDB entry: 1EQG; ref. 21) using the molecular docking program GOLD 4.0 (22). Ligand docking suggests that all three flavones can occupy the active site of COX-2. The binding mode for apigenin and tricin is very similar, whereas PMF shows a different orientation in the binding site. For PMF, tricin, and apigenin, the GOLD fitness scores, were 57.2, 52.8, and 51.3, respectively [110].

A virtual screening using an automated docking study using CDOCKER (Accelrys Inc., San Diego, CA) with the CHARMm force field,450 flavonoids and human peroxisome proliferator-activated receptor gamma $\mathrm{hPPAR} \gamma$ (code: $2 \mathrm{PRG}$ and $1 \mathrm{~K} 74$ ) was performed by Lee and co-workers [111]. HPPAR $\gamma$ regulates the proliferation, apoptosis, and differentiation of various human cancer cells, including lung, breast, colon, and prostate cancer cells. Among the selected eight flavonoids (four flavones, two flavonols, and two isoflavones), the authors highlighted that compound 3,6dihydroxyflavone (Fig. 23) is a novel agonist of PPAR $\gamma$, with cytotoxic activity against human cervical and prostate cancer cells [111]. Other recent study of the same research group proposes a binding model of amentoflavone (Fig. 23), symmetric biflavonoid (homodimer of apigenins), and hPPAR $\gamma$ (code: 2PRG). Computations were performed using CDOCKER (Accelrys Inc., San Diego, USA) with the CHARMM force field. The docking results show that three hydrogen bonds and two hydrophobic interactions are responsible to the strong binding of amentoflavone to hPPAR $\gamma$ [112].

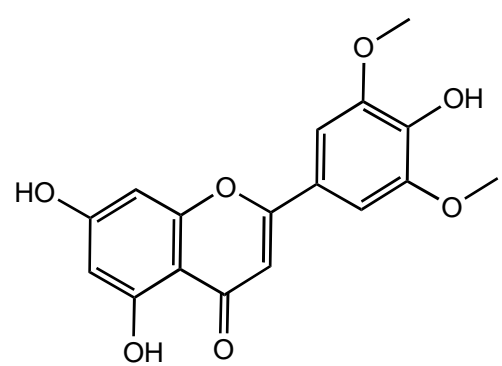

a<smiles>COc1cc(OC)c2c(=O)cc(-c3cc(OC)c(OC)c(OC)c3)oc2c1</smiles>

b

Fig. (22). Structures of (a) tricin and (b) 3',4',5',5,7-pentamethoxyflavone.<smiles>O=c1c(O)c(-c2ccccc2)oc2ccc(O)c(O)c12</smiles>

a<smiles>O=c1cc(-c2ccc(O)c(-c3c(O)cc(O)c4c(=O)cc(-c5ccc(O)cc5)oc34)c2)oc2cc(O)cc(O)c12</smiles>

b

Fig. (23). Structures of (a) 3,6-dihydroxyflavone and (b) amentoflavone. 
Docking results of P-glycoprotein, multidrug resistance and breast cancer resistance protein [113], and flavonoids aided 3D-QSAR studies [26]. The structures of the flavone derivatives and their biological activities of forty two compounds were taken from the literature [114]. The authors used the most active compound to perform molecular docking studies using the computational program Autodock 4.0 [115] and final structures were ranked according to the Autodock scoring function. The top binding mode was selected and used for receptor-guided CoMFA and CoMSIA analysis [35].

Ehrman and co-workers described an interesting in silico study to select multi-target anti-inflammatory agents from a data set of 192 metabolites [116], including flavonoids, isolated from over 50 Chinese herbs, using the computational program LigandScout and several targets: cyclo-oxygenases 1 and 2 (COX), p38 MAP kinase (p38), c-Jun terminal-NH2 kinase (JNK), which the inhibition is related to the treatment of cancer disease [117] and type 4 cAMP-specific phosphodiesterase (PDE4). Other multi-target study selected of 28 plant-derived compounds, mainly flavonoids, that exhibit anticancer activity, were subjected to docking simulations, using AutoDock 3.0.5, with different enzymes and receptor proteins involved with cell cycle, cell growth, and DNA replication: cyclin-dependent protein kinase 2 (CDK-2), CDK6 , DNA topoisomerases I and II, B-cell lymphoma 2 (Bcl-2), vascular endothelial growth factor receptor 2 (VEGFR-2), and the telomere: G-quadruplexes. (respective pdb codes: 1DI8, 1XO2, 1T8I, 1ZXM, 2O2F, 2OH4, 1L1H). The authors focused into some structural features for every target based on docking results [118]. Several flavonoids were docked onto the proangiogenic peptides such as VEGF, hypoxia inducible factor (HIF-1a), and VEGFR2 from human origin [119]. Hypoxia inducible factor-1a (HIF-1a) is basically a hypoxia-induced transcription factor. Its expression has been reported to be elevated in many human cancers [120] ArgusLab 4.0.1. (Mark Thompson and Planaria Software LLC) was used for performing molecular docking experiments. The X-ray crystallographic structures of the human VEGF (1vpp/pdb), human HIF-1a (1yci/pdb) and human VEGFR2 (1ywn/pdb) were downloaded online (www.rcsb.org) from the Research Collaboratory for Structural Bioinformatics (RCSB). The authors highlighted the results obtained from genistein (Fig. 24), kaempferol (Fig. 16), and quercetin (Fig. 16).

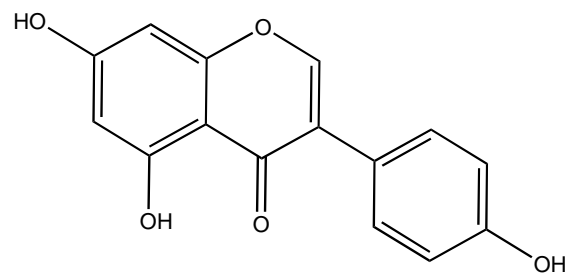

Fig. (24). Structure of genistein.

\section{CONCLUDING REMARKS AND FUTURE PERSPEC- TIVES}

We have tabulated and discussed the most important structural information of anticancer flavonoids. A large number of studies of SAR, QSAR, 2D and 3D QSAR models have been calculated and determined in an attempt to identify and understand the rational basis behind the medicinal chemistry of these compounds.

Most of these QSAR studies used structural descriptors, but we noted that the reason to choose a descriptor varies a lot and depends on the overall aim. For example, the potency of an antioxidant flavonoid is the largest benefit that these compounds provide to our health, including reducing cell damage, preventing cancer and inhibiting its advance. In computational studies that attempt to correlate the chemical structure of flavonoids with antioxidant activity; electronic descriptors and of enthalpy are selected.

On the other hand, the importance of docking models to the medicinal chemistry of anticancer flavonoids has increased in the last decade, especially to help in identifying the structural determinants responsible for the activity. Therefore, we also discussed the use of docking models, together with QSAR models, for the virtual screening of anticancer flavonoids. We tabulated here the most important examples of virtual screening determined for anticancer flavonoids and we highlighted the structural features. The mode of action, the most potent anticancer flavonoids and hints for the structural design of anticancer flavonoids are revised in details and provided here.

Future perspectives in the discovery of flavonoids with anticancer activity may be focused on the use of novel and recently reported QSAR studies, which allow simultaneous prediction and virtual screening of compounds with the desired biological activity [24-26, 121-136]. These promising methodologies could be of great help in chemotaxonomic studies, the fast and efficient detection of flavonoids from different plant species, and at the same time, with the computer-aided selection of these versatile natural products as anticancer agents.

\section{CONFLICT OF INTEREST}

The author(s) confirm that this article content has no conflicts of interest.

\section{ACKNOWLEDGEMENTS}

We have received funds along the years by $\mathrm{CNPq}$, CAPES and FAPESQ. I. R. P. is thankful to the INCT_if; D.R.M.M. holds a FAPESB scholarship of post-doctoral an L. S. holds a CNPq scholarship of post-doctoral.

\section{LIST OF ABBREVIATIONS}

1TQA $=$ Cytochrome $\mathrm{P} 450$ aromatase

2D $=$ Two dimensional

3D

$=$ Three dimensional

4-OHE2

$=$ 4-hydroxyestradiol

A549

$=$ Adenocarcinomic human alveolar basal epithelial cells

ANF $\quad=\alpha$-naphthoflavone

ATP

$=$ Adenosine triphosphate

ABCG2
= ATP-binding cassette sub-family G member 2 


\begin{tabular}{|c|c|}
\hline BCRP & $=$ Breast cancer resistance protein \\
\hline BPNN & $=$ Back-propagation neural network \\
\hline BRNN & $=$ Bayesian-regularized neural network \\
\hline CDKs & $=$ Cyclin dependent kinases \\
\hline CART & $\begin{array}{l}=\text { Configuration of classification and regres- } \\
\text { sion trees }\end{array}$ \\
\hline $\mathrm{CHCD}$ & $=$ Chinese Herbal Constituents Database \\
\hline Clog $\mathrm{P}$ & $=\begin{array}{l}\text { Logarithm of partition coefficient (Lipo- } \\
\text { philicity) }\end{array}$ \\
\hline CoMFA & $=$ Comparative molecular field analysis \\
\hline CoMSIA & $\begin{array}{l}=\begin{array}{l}\text { Comparative molecular similarity indices } \\
\text { analysis }\end{array}\end{array}$ \\
\hline ERK- I & $\begin{array}{l}=\text { Extracellular signal-regulated kinase acti- } \\
\text { vation }\end{array}$ \\
\hline GAFF & $=$ General AMBER force field \\
\hline GSK-3b & $=$ Glycogen synthase kinase- $3 \mathrm{~b}$ \\
\hline HCT116 & $=$ Colon cancer cell lines \\
\hline HO8910 & $=$ Human epithelial ovarian cancer cells \\
\hline H-bond & $=$ Hydrogen bond \\
\hline K562 & $\begin{array}{l}=\text { Human erythromyeloblastoid leukemia cell } \\
\text { line }\end{array}$ \\
\hline $\mathrm{Kd}$ & $=$ Dissociation constant \\
\hline LMO & $=$ Leave-many- out \\
\hline LOO & $=$ Leave-one-out \\
\hline MCF-7 & $=$ Breast cancer cell lines \\
\hline MEK1 & $\begin{aligned}= & \text { Mitogen-activated protein } \\
& \text { kinase/extracellular signal-regulated kinase }\end{aligned}$ \\
\hline MMFF94s & $=$ Merck Molecular Force Field \\
\hline MIFs & $=$ Molecular interaction fields \\
\hline MHBP & $\begin{array}{l}=\begin{array}{l}\text { Molecular hydrogen bound potential (ac- } \\
\text { ceptor) }\end{array}\end{array}$ \\
\hline $\mathrm{MHBP}_{\mathrm{d}}$ & $\begin{array}{l}=\begin{array}{l}\text { Molecular hydrogen bound potential (do- } \\
\text { nor) }\end{array}\end{array}$ \\
\hline $\mathrm{MLP}_{\mathrm{ho}}$ & $=$ Hydrophobic molecular lipophilic potential \\
\hline MPSOCART & $=$ Globally optimal CART \\
\hline $\mathrm{NFjB}$ & $=$ Abrogating nuclear factor $\mathrm{jB}$ \\
\hline NF- $\kappa B$ & $\begin{aligned}= & \text { Nuclear factor kappa-light-chain-enhancer } \\
& \text { of activated B cells }\end{aligned}$ \\
\hline$q^{2}$ & $=$ Cross-validation correlation coefficient \\
\hline QSAR & $=$ Quantitative structure-activity relationship \\
\hline PI3K & $=$ Phosphatidylinositol 3-kinase \\
\hline PC-3 & $=$ Human prostate cancer cell lines \\
\hline PCs & $=$ Principal components \\
\hline PCA & $=$ Principal components analysis \\
\hline P-gp & $=\mathrm{P}$-glycoprotein 1 \\
\hline
\end{tabular}

$\begin{array}{ll}\text { Pim-1 } & \text { Proto-oncogene serine/threonine-protein } \\ \text { PLS } & =\text { Partial Least Squares } \\ \mathrm{r}^{2} & =\text { Non-cross-validation coefficient } \\ \text { Raf1 } & =\text { Rapidly Accelerated Fibrosarcoma } \\ \text { RF } & =\text { Random Forest } \\ \text { ROO• } & =\text { Radical oxygen } \\ \text { ROS } & =\text { Reactive oxygen species } \\ \text { RSK2 } & =\text { Ribosomal S6 kinase } 2 \\ \text { SAR } & =\text { Structure-activity relationship } \\ \text { SKHep1 } & =\text { Hepatocellular carcinoma } \\ \text { SED } & =\text { Substituent electronic descriptors } \\ \text { TCM } & =\text { Traditional Chinese medicine } \\ \text { TNF } \alpha & =\text { Tumor necrosis factor } \alpha\end{array}$

\section{REFERENCES}

[1] Pannala, A.S.; Chan, S.T.; O’Brien J.P.; Rice-Evans A.C. Flavonoid B-ring chemistry and antioxidant activity: fast reaction kinetics. Biochem. Biophys. Res. Commun., 2001, 282, 1161-1168.

[2] Rolim, A.; Oishi, T.; Maciel, C.P.M.; Zague, V.; Pinto, C.A.S.O.; Kaneko, T.M.; Consiglieri, V.O.; Velasco, M.V.R. Total flavonoids quantification from $\mathrm{O} / \mathrm{W}$ emulsion with extract of Brazilian plants, Int. J. Pharm., 2006, 308, 107-114.

[3] Vaya, J.; Mahemood, S.; Goldblum, A.; Aviram, M.; Volkova, N.; Shaalan, A.; Musa, R.; Tamir, S. Inhibition of LDL oxidation by flavonoids in relation to their structure and calculated enthalpy.Phytochem., 2003, 62, 89-99.

[4] Cardoso, C.L.; Silva, D.H.S.; Castro-Gamboa, I.; Bolzani, V.S New biflavonoid and other flavonoids from the leaves of Chimarrhis turbinata and their antioxidant activities, J. Braz. Chem. Soc., 2005, 16, 1353-1359.

[5] Farkas, O.; Jakus, J.; Héberger, K. Quantitative structure antioxidant activity relationships of flavonoid compounds. Molecules, 2004, 9, 1079-1088.

[6] Hyun, J.; Shin, S.Y.; So K.M.; Lee Y.H.; Lim Y. Isoflavones inhibit the clonogenicity of human colon cancer cells. Bioorg. Med. Chem. Lett., 2012, 22, 2664-2669.

[7] Shin, S.Y.; Woo, Y.; Hyun, Y.; Dongsoo, K.; Lee, Y.H.; Lim, Y. Relationship between the structures of flavonoids and their NF- $\mathrm{KB}$ dependent transcriptional activities. Bioorg. Med. Chem. Letters, 2011, 21, 6036-6041.

[8] Ou, L.; Han, S.; Ding, W.; Chen, Z.; Ye, Z.; Yang, H.; Zhang, G.; Lou, Y.; Chen, J.-Z.; Yu, Y. Design, synthesis and 3D-QSAR study of cytotoxic flavonoid derivatives. Mol. Divers., 2011, 15, 665-675.

[9] Weng, C.J.; Yen, G.-C. Chemopreventive effects of dietary phytochemicals against cancer invasion and metastasis: Phenolic acids, monophenol, polyphenol, and their derivatives. Cancer Treat. Rev., 2012, 38, 76-87.

[10] Todeschini, R.; Consonni, V. Molecular Descriptors for Chemoinformatics, WILEY-VCH Verlag GmbH \& Co. KGaA: Weinheim, 2009.

[11] Scotti, L.; Velasco, M.V.R. Envelhecimento cutâneo à luz da Cosmetologia, Tecnopress: São Paulo, 2003.

[12] Scotti, L.; Scotti, M.T.; Pasqualoto, K.F.M.; Bolzani, V.S. Molecular physicochemical parameters predicting antioxidant activity of Brazilian natural products. Braz. J. Pharmacogn., 2009, 19, 908913.

[13] Scotti, L.; Scotti, M.T.; Cardoso, C.L.; Pauletti, P.M.; Gamboa, I.C.; Bolzani, V.S.; Velasco, M.V.R.; Menezes, C.M.S.; Ferreira, E.I. Modelagem molecular aplicada ao desenvolvimento de moléculas com atividade antioxidante visando ao uso cosmético. Rev. Bras. Cienc. Farm., 2007, 43, 153-166.

[14] Cheng, Z.; Ren, J.; Yan, G.; Li, Y.; Chang, W.; Chen, Z. Quantitative elucidation of the molecular mechanisms of hydroxyl radical 
quenching reactivity of phenolic compounds. Bioorg. Chem., 2003, $31,149-162$

[15] Zhang, Y. Theoretical methods used in elucidating activity differences of phenolic antioxidants, J. Am. Oil Chem. Soc., 1999, 76, 745-748.

[16] Cao, H.; Cheng, W.X.; Li, C.; Pan, X.L.; Xie, X.G., Li, T.H. DFT study on the antioxidant activity of rosmarinic acid, J. Mol. Struct. (Theochem), 2005, 719, 177-183.

[17] Zhang, S.; Yang, X.; Coburn, R.A.; Morris, M.E. Structure activity relationships and quantitative structure activity relationships for the flavonoid-mediated inhibition of breast cancer resistance protein. Biochem. Pharmacol., 2005, 70, 627-639.

[18] Gandhi, Y.A.; Morris, M.E. Structure-activity relationships and quantitative structure-activity relationships for breast cancer resistance protein (ABCG2). AAPS J., 2009, 11, 541-552.

[19] Xie, Y.; Linn, D. E.; Yang, X.; Guo, Z; Shimelis, H.; Nakanishi, T.; Ross, D. D.; Chen, H.; Fazli, L.; Gleave, M. E.; Qiu, Y. The 44kDa Pim-1 kinase phosphorylates BCRP/ABCG2 and thereby promotes its multimerization and drug-resistant activity in human prostate cancer cells. J. Bio. Chem., 2008, 283, 3349-3356.

[20] Pick, A.; Müller, H.; Mayer, R.; Haenisch, B.; Pajeva, I.K.; Weigt, M.; Bönisch, H.; Müller, C.E.; Wiese, M. Structure-activity relationships of flavonoids as inhibitors of breast cancer resistance protein (BCRP). Bioorg. Med. Chem., 2011, 19, 2090-2102.

[21] Cheng, Z.; Ren, J.; Li, Y.; Chang, W.; Chen, Z. Study on the multiple mechanisms underlying the reaction between hydroxyl radical and phenolic compounds by qualitative structure and activity relationship. Bioorg. Med. Chem., 2002, 10, 4067-1073.

[22] Saija, A.; Tomaino, A.; Trombetta, D.; Pasquale, A.D.; Uccella, N.; Barbuzzi, T.; Paolino, D.; Bonina, F. In vitro and in vivo evaluation of caffeic and ferulic acids as topical photoprotective agents, Int. J. Pharm., 2000, 199, 39-47.

[23] Ghose, A.K.; Pritchett, A.; Crippen, G.M. Atomic physicochemical parameters of three dimensional structure directed quantitative structure-activity relationships III: Modeling hydrophobic interactions. J. Comput. Chem., 1988, 9, 80-90.

[24] Speck-Planche, A.; Kleandrova, V.V.; Luan F.; Cordeiro, M.N.D.S. Chemoinformatics in multi-target drug discovery for anti-cancer therapy: in silico design of potent and versatile anti-brain tumor agents. Anti-Cancer Agent. Med. Chem., 2012, 12, 678-685.

[25] Speck-Planche, A.; Kleandrova, V.V.; Luan F.; M.N.D.S. Cordeiro. Rational drug design for anti-cancer chemotherapy: Multi-target QSAR models for the in silico discovery of anti-colorectal cancer agents. Bioorg. Med. Chem., 2012, 20, 4848-4855.

[26] Speck-Planche, A.; Kleandrova, V.V.; Luan F.; M.N.D.S. Cordeiro. Chemoinformatics in anti-cancer chemotherapy: Multi-target QSAR model for the in silico discovery of anti-breast cancer agents. Eur. J. Pharm. Sci., 2012, 47, 273-279.

[27] Scotti, M.T.; Fernandes, M.B.; Ferreira, M.J.P.; Emereciano, V.P.; Quantitative structure-activity relationship of sesquiterpene lactones with cytotoxic activity. Bioorg. Med. Chem., 2007, 15, 29272934.

[28] Aguiar-Pulido V.; Munteanu, C.R.; Seoane, J.A.; FernándezBlanco E.; Pérez-Montoto L.G.; González-Díaz H.; Dorado, J.; Naïve Bayes QSDR classification based on spiral-graph Shannon entropies for protein biomarkers in human colon cancer. Mol. BioSyst., 2012, 8, 1716-1722.

[29] Martínez-Romero, M.; Vázquez-Naya, J.M.; Rabuñal, J.R.; PitaFernández, S.; Macenlle, R.; Castro-Alvariño, J.; López-Roses, L.;Ulla, J.L.; Martínez-Calvo, A.V.; Vázquez, S.; Pereira, J.;PortoPazos, A.B; Dorado, J.; Pazos, A.; Munteanu, C.R. Artificial intelligence techniques for colorectal cancer drug metabolism: ontologies and complex networks. Curr. Drug Metab., 2010, 11, 347-368. Munteanu C.R.,; Magalhães A.L.; Uriarte, E.; González-Díaz H.; Multi-target QPDR classification model for human breast and colon cancer-related proteins using star graph topological indices. $J$. Theor. Biol., 2009, 257, 303-311.

[31] Fernández-Blanco E.; Aguiar-PulidoV.; Munteanu, C.R.; Dorado, J.; Random Forest classification basedon star graph topological indices for antioxidant proteins. J. Theor. Biol., 2013, 317, 331-337.

[32] Burda, S.; Oleszek, W. Antioxidant and antiradical activities of flavonoids. J. Agric. Food Chem., 2001, 49, 2774-2779.

[33] Bandgar, B.P.; Gawande, S.S.; Bodade, R.G.; Totre, J.V.; Khobragade, C.N. Synthesis and biological evaluation of simple methoxylated chalcones as anticancer, anti-inflammatory and antioxidant agents. Bioorg. Med. Chem., 2010, 18, 1364-1370.
[34] Reddy, M.V.B.; Shen, Y.C.; Ohkoshi, E.; Bastow, K.F.; Qian, K.; Lee, K.-H.; Wu, T.S. Bis-chalcone analogues as potent NO production inhibitors and as cytotoxic agents. Eur. J. Med. Chem., 2012, 47, 97-103.

[35] Kothandan, G.; Gadhe, C.G.; Madvhan, T.; Choi, C.H.; Cho, S.J. Docking and 3D-QSAR (quantitative structure activity relationship) studies of flavones, the potent inhibitors of p-glycoprotein targeting the nucleotide binding domain. Eur. J. Med. Chem., 2011, 46, 4078-4088.

[36] Boccard, J.; Bajot, F.; Di Pietro, A.; Rudaz, S.; Boumendjel, A.; Nicolle, E.; Carrupt, P.A. A 3D linear solvation energy model to quantify the affinity of flavonoid derivatives towards Pglycoprotein. Eur. J. Pharm. Sci., 2009, 36, 254-264.

[37] Holder, S.; Lilly, M.; Brown, M. Comparative molecular field analysis of flavonoid inhibitors of the PIM-1 kinase, Bioorg. Med. Chem., 2007, 15, 6463-6473.

[38] Tropsha, A.; Gramatica, P.; Gombar, V.K. The importance of being earnest: validation is the absolute essential for successful application and interpretation of QSPR models. QSAR Comb. Sci., 2003, 22, 69-77.

[39] Höltje, H.D.; Sippl, W.; Rognan, D.; Folkers, G. Molecular Modeling. Basic Principles and Applications, $3^{\text {rd }}$ ed.; Wiley-VCH: Weinheim, 2008.

[40] Bhattacharjee, A.K.; Kyle, D.E.; Vennrstrom, J.L.; Milhous, W.K. A 3D QSAR Pharmacophore Model and Quantum Chemical Structure-Activity Analysis of Chloroquine(CQ)-Resistance Reversal. $J$. Chem. Inf. Comput. Sci., 2002, 42, 1212-1220.

[41] Środa, K.; Michalak, K.; Maniewska J.; Gynkiewicz, G.; Szeja, W.; Szeja, W.; Zawisza, J.; Hendrich, A.B. Genistein derivatives decrease liposome membrane integrity-Calcein release and molecular modeling study. Biophys. Chem., 2008, 138, 78-82.

[42] Seyoum, A.; Asres, K.; El-Fiky, F.K. Structure-radical scavenging activity relationships of flavonoids. Phytochemistry, 2006, 67, 2058-2070.

[43] Scotti, L.; Scotti, M.T.; Bolzani, V.S.; Ferreira, E.I. Molecular physicochemical parameters predicting antioxidant activity of Brazilian Natural Products. Rev. Bras. Farmacogn., 2010, 19, 908-913.

[44] Singh, R.; Jain, A.; Ravichandran, V.; Mourya, V.; Agrawal, R.K. Prediction of antiproliferative activity of some flavone derivatives: QSAR study. Med. Chem. Res., 2009, 18, 523-537.

[45] Wang, T.; Chen, I.L.; Lu, P.J.; Wong, C.H.; Liao, C.H.; Tsiao, K.C.; Chang, K.M.; Chen, Y.L.; Tzeng, C.C. Synthesis, and cytotoxic and antiplatelet activities of oxime- and methyloximecontaining flavone, isoflavone, and xanthone derivatives. Bioorg. Med. Chem., 2005, 13, 6045-6053.

[46] Fassihi, A.; Sabet, R. QSAR Study of p56lck protein tyrosine kinase inhibitory activity of flavonoid derivatives using MLR and GA-PLS. Int. J. Mol. Sci., 2008, 9, 1876-1892.

[47] Goodford, P.J. A computational procedure for determining energetically favorable binding sites on biologically important macromolecules. J. Med. Chem., 1985, 28, 849-857.

[48] Cramer, R.D.; Patterson, D.E.; Bunce, J.D. Comparative Molecular Field Analysis (CoMFA). 1. Effect of Shape on Binding of Steroids to Carrier Proteins. J. Am. Chem. Soc., 1988, 110, 5959-5967.

[49] Nicolle, E.; Boccard, J.; Guilet, D.; Dijoux-Franca, M.G.; Zelefac, F.; Macalou, S.; Grosselin, J.; Schmidt, J.; Carrupt, P.-A.; Pietro, A.D.; Boumendjel, A. Breast cancer resistance protein (BCRP/ABCG2): New inhibitors and QSAR studies by a 3D linear solvation energy approach. Eur. J. Pharm. Sci., 2009, 38, 39-46.

[50] Cruciani, G.; Crivori, P.; Carrupt, P.A.; Testa, B. Molecular fields in quantitative structure permeation relationships: the VolSurf approach. J. Mol. Struct.-Theochem, 2000, 503, 17-30.

[51] Scotti, L.; Fernandes, M.B.; Maramatsu, E.; Pasqualoto, K.F.M.; Emerenciano, V.P.; Tavares, L.C.; Silva, M.S.; Scotti, M.T. Selforganizing maps and VolSurf approach to predict aldose reductase inhibition by flavonoid compounds. Rev. Bras. Farmacogn., 2011, 21, 170-180.

[52] Pietro, A.D.; Conseil, G.; Perez-Victoria, J.M.; Dayan, G.; Baubichon-Cortay, H.; Trompier, D.; Stein-Fels, E.; Jault, J.M.; De Wet, H.; Maitrejean, M.; Comte, G.; Boumendjel, A.; Mariotte, A.M.; Dumontet, C.; McIntosh, D.B.; Goffeau, A.; Castanys, S. Gamarro, F.; Barron, D. Modulation by flavonoids of cell multidrug resistance mediated by P-glycoprotein and related ABC transporters. Cell. Mol. Life Sci., 2002, 59, 307-322. 
[53] Cheng, Z.J.; Zhang, Y.T.; Fu, W.Z. QSAR study of carboxylic acid derivatives as HIV-1 integrase inhibitors, Eur. J. Med. Chem., 2010, 45, 3970-3980.

[54] Wang, Z.Z.; Li, Y.; Ai, C.Z.; Wang, Y.H. In silico prediction of estrogen receptor subtype binding affinity and selectivity using statistical methods and molecular docking with 2-arylnaphthalenes and 2-arylquinolines. Int. J. Mol. Sci., 2010, 11, 3434-3458.

[55] Wang, Y.H.; Li, Y., Yang, S.L.; Yang, L. An in silico approach for screening flavonoids as P-glycoprotein inhibitors based on a Bayesian-regularized neural network. J. Comput. Aided Mol. Des., 2005, 19, 137-147.

[56] Weber, K.C.; Honório, K.M.; Bruni, A.T.; Andricopulo, A.D.; Silva, A.B.F. A partial least squares regression study with antioxidant flavonoid compounds. Struct. Chem., 2006, 17, 307-313.

[57] Rouer, E.; Expression of the p56lck by colon tumors: a marker of their invasive capacity? B. Cancer, 2004, 91, 928-940.

[58] Niikolovska-Coleska, Z.; Suturkova, L.; Krbavic, A.; Solmayer, T. Quantitative structure-activity relationship of flavonoid inhibitors of p561ck protein tyrosine kinase: a classical/quantum chemical approach. Quant. Struct.-Act. Relat., 1998, 17, 7-13.

[59] Zhou, Y.P.; Tang, L.J., Jiao, J., Song, D.D.; Jiang, J.H.; Yu, R.Q. Modified particle swarm optimization algorithm for adaptively configuring globally optimal classification and regression trees, $J$. Chem. Inf. Model. 2009, 49, 1144-1153.

[60] Kubinyi H., 3D QSAR in Drug Design. Theory, Methods and Applications, ESCOM, Science Publishers B.V.: Leiden, 1993.

[61] Cassidy, C.E.; Setzer, W.N. Cancer-relevant biochemical targets of cytotoxic Lonchocarpus flavonoids: A molecular docking analysis. J. Mol. Model., 2010, 16, 311-326.

[62] Rodriguez-Antona, C.; Ingelman-Sundberg, M. Cytochrome P450 pharmacogenetics and câncer. Oncogene, 2006, 25, 1679-1691.

[63] Paoletta, S.; Steventon, G.B.; Wildeboer, D.; Ehrman, T.M.; Hylands P.J.; Barlow, D.J. Screening of herbal constituents for aromatase inhibitory activity. Bioorg. Med. Chem., 2008, 16, 84668470

[64] Ehrman T.M.; Barlow, D.J.; Hylands, P.J.; Phytochemical databases of Chinese herbal constituents and bioactive plant compounds with known target specificities. J. Chem. Inf. Model., 2007, 47, 254-263.

[65] Gobbi, S.; Cavalli, A.; Bisi, A.; Recanatini, M.; From nonsteroidal aromatase inhibitors to multifunctional drug candidates: classic and innovative strategies for the treatment of breast cancer. Curr. Top. Med. Chem., 2008, 8, 869-887.

[66] Benson, J.R.; Ravisekar, O. Aromatase Inhibitors for Treatment of Breast Cancer.Curr. Cancer Treat.Rev., 2007, 3, 67-79.

[67] Brueggemeier, R.W.; Hackett, J.C.; Diaz-Cruz, E.S. Aromatase inhibitors in the treatment of breast cancer. Endocr. Rev., 2005, 26, 331-345.

[68] Hall, L.H.; Kier, L.B. The molecular connectivity chi indexes and kappa shape indexes in structure-property modeling. Rev. Comput. Chem., 1991, 2, 367-422.

[69] Labute, P.A.J. A widely applicable set of descriptors. Mol. Graphics Modell., 2000, 18, 464-477.

[70] Favia, A. D.; Cavalli, A.; Masetti, M.; Carotti, A.; Recanatini, M. Three-dimensional model of the human aromatase enzyme and density functional parameterization of the iron-containing protoporphyrin IX for a molecular dynamics study of heme-cysteinato cytochromes. Proteins Struct.Funct. Bioinform., 2006, 62, 10741087.

[71] Rarey, M.; Kramer, B.; Lengauer, T.; Klebe, G. A fast flexible docking method using an incremental construction algorithm. $J$. Mol. Biol., 1996, 261, 470-489.

[72] Takemura, H.; Itoh, T.; Yamamoto, K.; Sakakibara, H.; Shimoi, K. Selective inhibition of methoxyflavonoids on human CYP1B1 activity. Bioorg. Med. Chem., 2010, 18, 6310-6315.

[73] Sansen, S.; Yano, J.K.; Reynald, R.L.; Schoch, G.A.; Griffin, K.J.; Stout, C.D.; Johnson, E.F. Adaptations for the oxidation of polycyclic aromatic hydrocarbons exhibited by the structure of human P450 1A2. J. Biol. Chem., 2007, 282, 14348-14355.

[74] He, L.; He, F.; Bi, H.; Li, J.; Zeng, S.; Luo, H.; Huang, M. Isoformselective inhibition of chrysin towards human cytochrome P450 1A2. Kinetics analysis, molecular docking, and molecular dynamics simulations. Bioorg. Med. Chem. Lett., 2010, 20, 6008-6012.

[75] Wu, G.; Robertson, D.H.; Brooks, C.L.; Vieth, M. Detailed analysis of grid-based molecular docking: A case study of CDOCKER-
A CHARMm-based MD docking algorithm. J. Comput. Chem., 2003, 24, 1549-1562.

[76] Shimada, T.; Tanaka, K.; Takenaka, S.; Murayama, N.; Martin, M.V.; Foroozesh, M.K.; Yamazaki, H.; Guengerich, F.P.; Komori, M. Structure-function relationships of inhibition of human cytochromes P450 1A1, 1A2, 1B1, 2C9, and 3A4 by 33 flavonoid derivatives. Chem. Res. Toxicol., 2010, 23, 1921-1935.

[77] Wester, M.R.; Yano, J.K.; Schoch, G.A.; Yang, C.; Griffin, K.J.; Stout, C.D.; Johnson, E.F. The structure of human cytochrome P450 2C9 complexed with flurbiprofen at 2.0-A resolution. J. Biol. Chem., 2004, 279, 35630-35637.

[78] Yano, J.K.; Wester, M.R.; Schoch, G.A.; Griffin, K.J.; Stout, C.D.; Johnson, E.F.; The structure of human microsomal cytochrome P450 3A4 determined by X-ray crystallography to 2.05 - $\AA$ resolution. J. Biol. Chem., 2004, 279, 38091-38094.

[79] Androutsopoulos, V.P.; Papakyriakou, A.; Vourloumis, D.; Spandidos, D.A. Comparative CYP1A1 and CYP1B1 substrate and inhibitor profile of dietary flavonoids. Bioorg. Med. Chem., 2011, 19 2842-2849.

[80] Eswar, N.; John, B.; Mirkovic, N.; Fiser, A.; Ilyin, V. A.; Pieper, U.; Stuart, A. C.; Marti-Renom, M. A.; Madhusudhan, M. S.; Yerkovich, B.; Sali, A. Tools for comparative protein structure modeling and analysis. Nucleic Acids Res., 2003, 31, 3375-3380.

[81] Kirchmair, J.; Wolber, G.; Laggner, C.; Langer, T. Comparative performance assessment of the conformational model generators omega and catalyst: a large-scale survey on the retrieval of proteinbound ligand conformations. J. Chem. Inf. Model., 2006, 46, 18481861.

[82] Sanner, M. F. Python: A programming language for software integration and development. J. Mol. Graphics Modell., 1999, 17, 5761.

[83] Huey, R.; Morris, G.M.; Olson, A.J.; Goodsell, D.S. A semiempirical free energy force field with charge-based desolvation. J. Comput. Chem., 2007, 28, 1145-1152.

[84] Bonfield, K.; Amato, E.; Bankemper, T.; Agard, H.; Steller, J.; Keeler, J.M.; Roy, D.; McCallum, A; Paula, S.; Ma, L. Development of a new class of aromatase inhibitors: Design, synthesis and inhibitory activity of 3-phenylchroman-4-one (isoflavanone) derivatives. Bioorg. Med. Chem., 2012, 20, 2603-2613.

[85] Jones, G.; Willett, P.; Glen, R.C.; Leach, A.R.; Taylor, R. Development and validation of a genetic algorithm for flexible docking. J. Mol. Biol., 1997, 267, 727-748.

[86] Narayana, B.L.; Pran Kishore, D.; Balakumar, C.; Rao, K.V; Kaur, R.; Rao, A.R; Murthy, J.N.; Ravikumar, M. Molecular Modeling Evaluation of Non-Steroidal Aromatase Inhibitors. Chem. Biol. Drug. Des., 2012, 79, 674-682.

[87] Ghosh, D; Griswold, J.M.; Pangborn, W. Structural basis for androgen specificity and oestrogen synthesis in human aromatase. Nature, 2009, 457, 219-224.

[88] Bheemanapalli, L.N.; Kaur, A.; Arora, R.; Sangeeta; Akkinepally, R.R.; Javali, N.M. Synthesis, evaluation of 6,8-dibromo-2-aryl-2,3dihydroquinolin-4(1H)-ones in MCF-7 (breast cancer) cell lines and their docking studies. Med. Chem. Res., 2012, 21, 1741-1750.

[89] Shchemelinin, I.; Sefc, L.; Necas, E.; Protein kinases, their function and implication in cancer and other diseases. Folia Biol., 2006, 52, 81-100.

[90] Lee K.W. Kang, N.J., Heo, Y., Rogozin, E.A.; Pugliese, A. Hwang M. K.; Bowden G.T.; Bode, A.M.; Lee H.J.; Raf, Z.D.; MEK protein kinases are direct molecular targets for the chemopreventive effect of quercetin, a major flavonol in red wine. Cancer Res., 2008, 68,946-955.

[91] Gioeli D, Mandell JW, Petroni GR, Frierson HF, Jr., Weber MJ. Activation of mitogen-activated protein kinase associated with prostate cancer progression. Cancer Res., 1999, 59,279-284.

[92] Lee, K.M.; Lee, D.E.; Seo, S.K.; Hwang, M.K.; Heo, Y.; Lee, K.W.; Lee, H.J. Phosphatidylinositol 3-kinase, a novel target molecule for the inhibitory effects of kaempferol on neoplastic cell transformation. Carcinogenesis, 2010, 31, 1338-1343.

[93] Lee, K.M.; Lee, K.W.; Jung, S.K.; Lee, E.J.; Heo, Y.; Lee, H.J.; Dong, Z. Kaempferol inhibits UVB-induced COX-2 expression by suppressing Src kinase activity. Biochem. Pharmacol., 2010, 80, 2042-2049.

[94] Schwartzberg, P.L.; The many faces of Src: multiple functions of a prototypical tyrosine kinase. Oncogene, 1998, 17, 1463-1468.

[95] Johnson, J.L.; Rupasinghe, S.G; Stefani, F.; Schuler, M.A.; Mejia, E.G.; Citrus flavonoids luteolin, apigenin, and quercetin inhibit 
glycogen synthase kinase-3b enzymatic activity by lowering the interaction energy within the binding cavity. J. Med. Food., 2011, 14, 325-333.

[96] Patil, J.; Jayaprakasha, G.; Murthy, K.; Chetti, M.; Patil. B.; Characterization of Citrus aurantifolia bioactive compounds and their inhibition of pancreatic cancer cells through apoptosis. Microchem. J., 2010, 94, 108-117.

[97] Dong, X.; Zhou, X.; Jing, H.; Chen, J.; Liu, T.; Yang, B.; He, Q.; $\mathrm{Hu}$, Y.; Pharmacophore identification, virtual screening and biological evaluation of prenylated flavonoids derivatives as PKB/Akt1 inhibitors. Eur. J. Med. Chem., 2011, 46, 5949-5958.

[98] Sourbier, C.; Lindner, V.; Lang, H.; Agouni, A.; Schordan, E.; Danilin, S.; Rothhut, S.; Jacqmin, D.; Helwig, J.; Massfelder, T. The phosphoinositide 3-kinase/Akt pathway: a new target in human renal cell carcinoma therapy. Cancer Res., 2006, 66, 5130-5142.

[99] Venkatachalam, C.M.; Jiang, X.; Oldfield, T.; Waldman, M. LigandFit: a novel method for the shape-directed rapid docking of ligands to protein active sites. J. Mol. Graphics Model., 2003, 21, 289-307.

[100] Rao, S.N.; Head, M.S.; Kulkarni, A.; LaLonde, J.M. Validation Studies of the Site-Directed Docking Program LibDock. J. Chem. Inf. Model., 2007, 47, 2159-2171.

[101] Garrett, M.A. Cell cycle control and cancer. Curr. Sci., 2001, 81, 515-522.

[102] Khuntawee, W.; Rungrotmongkol, T.; Hannongbua T. Molecular dynamic behavior and binding affinity of flavonoid analogues to the cyclin dependent kinase 6/cyclin D complex. J. Chem. Inf. Model., 2012, 52, 76-83.

[103] Chen ,H.; Yao K.; Nadas J.; Bode A.M.; Malakhova,M.; Naomi Oi, N.; Li, H.; Lubet R.A.; Dong, Z. Prediction of molecular targets of cancer preventing flavonoid compounds using computational methods. PLoS One., 2012, 7, e38261

[104] Ciocca, D.R.; Calderwood, S.K. Heat shock proteins in cancer: diagnostic, prognostic, predictive, and treatment implications. Cell Stress Chaperon., 2005, 10, 86-103.

[105] Chen, C.Y.; Chen, G.; Chen W.Y. Molecular Simulation of HER2/neu Degradation by Inhibiting HSP90. J. Chin. Chem. SocTaip., 2008, 55, 297-302.

[106] Lee J.; Jung, K.; Kim, Y. inhibitor design for human heat shock protein 70 ATPase domain by pharmacophore-based in silico screening. Bull. Korean Chem. Soc., 2008, 29, 1717-1722.

[107] Deschamps, J.D.; Kenyon, V.A.; Holman, T.R. Baicalein is a potent in vitro inhibitor against both reticulocyte 15-human and platelet 12-human lipoxygenases. Bioorg. Med. Chem., 2006, 14, 42954301.

[108] Steele, V.E.; Holmes, C.A.; Hawk, E.T.; Kopelovich, L.; Lubet, R.A.; Crowell, J.A.; Sigman, C.C.; Kellof, G.J. Cancer Epidemiol. Biomarkers Prev., 1999, 8, 467-483.

[109] Takasawa, R.; Takahashi, S.; Saeki, K.; Sunaga, S.; Yoshimori, A.; Tanuma, S. Structure-activity relationship of human GLO I inhibitory natural flavonoids and their growth inhibitory effects. Bioorg. Med. Chem., 2008, 16, 3969-3975.

[110] Cai H.; Sale S.; Schmid, R.; Britton R.G.; Brown, K.; Steward, W.P.; Gescher, A.J.; Flavones as Colorectal Cancer Chemopreventive Agents-Phenol-OMethylation Enhances Efficacy. Cancer Prev. Res., 2009, 2, 743-750.

[111] Lee, J.; Kim, J.; Cho, M.; Shin, S.; Yoon, D.; Heo, Y.S.; Kim Y.; Cytotoxic Flavonoids as Agonists of Peroxisome ProliferatorActivated Receptor $\gamma$ on Human Cervical and Prostate Cancer Cells. J. Nat. Prod., 2010, 73, 1261-1265.

[112] Lee, J.; Kim, J.; Lee. S.; Lee, E.; Shin, S.; Jin, Q.; Yoon, D.; Woo, E.; Kim Y.; Binding model of amentoflavone to peroxisome proliferator-activated receptor $\gamma$. Bull. Korean Chem. Soc., 2012, 33, 1475-1479.

[113] Maliepaard, M.; van Gastelen, M.A.; de Jong, L.A.; Pluim, D.; van Waardenburg, R.C.; Ruevekamp-Helmers, M.C.; Floot, B.G.; Schellens, J.H. Overexpression of the BCRP/MXR/ABCP gene in a topotecan-selected ovarian tumor cell line. Cancer Res., 1999, 59, 4559-4563.

[114] Boumendjel, A.; Di Pietro A.; Dumontet, C.; Barron, D. Recent advances in the discovery of flavonoids and analogs with highaffinity binding to P-glycoprotein.responsible for cancer cell multidrug resistance. Med. Res. Rev., 2002, 22, 512-529.

[115] Morris, G.M.; Goodsell, D.S.; Halliday, R.S.; Huey, R.; Hart, W.E.; Belew, R.K.; Olson, A.J. Automated docking using a La- marckian genetic algorithm and an empirical binding free energy function. J. Comput. Chem., 1998, 19, 1639-1662.

[116] Ehrman, T.M.; Barlow, D.J.; Hylands, P.J. In silico search for multi-target anti-inflammatories in Chinese herbs and formulas. Bioorg. Med. Chem., 2010, 18, 2204-2218.

[117] Manning, A. M.; Davis, R. J. Targeting JNK for therapeutic benefit: from junk to gold? Nat. Rev. Drug Disc., 2003, 2, 554-565.

[118] Phosrithong, N.; Ungwitayatorn, J. Molecular docking study on anticancer activity of plant-derived natural products. Med. Chem. Res., 2010, 19, 817-835.

[119] Gacche, R.N.; Shegokar, H.D.; Gond, D.S.; Yang, Z.; Jadhav, A.D. Evaluation of selected flavonoids as antiangiogenic, anticancer, and radical scavenging agents: an experimental and in silico analysis. Cell Biochem. Biophys., 2011, 61, 651-663

[120] Zhong, H.; De Marzo, A.M.; Laughner, E.; Lim, M.; Hilton, D.A.; Zagzag, D. Buechler, P.; Isaacs, W.B.; Semenza, G.L.; Simons, J.W. Overexpression of hypoxia-inducible factor-1 alpha in common human cancers and their metastases. Cancer Res., 1999, 59, 5830-5835.

[121] Vina, D.; Uriarte, E.; Orallo, F.; Gonzalez-Diaz, H. Alignment-free prediction of a drug-target complex network based on parameters of drug connectivity and protein sequence of receptors. Mol. Pharm., 2009, 6, 825-835.

[122] Speck-Planche, A.; Luan, F.; Cordeiro, M.N. Role of ligand-based drug design methodologies toward the discovery of new antiAlzheimer agents: futures perspectives in Fragment-Based Ligand Design. Curr. Med. Chem., 2012, 19, 1635-1645.

[123] Speck-Planche, A.; Kleandrova, V.V.; Scotti, M.T. Fragment-based approach for the in silico discovery of multi-target insecticides. Chemometr. Intell. Lab. Syst., 2012, 111, 39-45.

[124] Speck-Planche, A.; Kleandrova, V.V.; Luan, F.; Cordeiro, M.N. Predicting multiple ecotoxicological profiles in agrochemical fungicides: a multi-species chemoinformatic approach. Ecotoxicol. Environ. Saf., 2012, 80, 308-313.

[125] Speck-Planche, A.; Kleandrova, V.V.; Luan, F.; Cordeiro, M.N. A ligand-based approach for the in silico discovery of multi-target inhibitors for proteins associated with HIV infection. Mol. Biosyst., 2012, 8, 2188-2196.

[126] Speck-Planche, A.; Kleandrova, V.V. In silico design of multitarget inhibitors for C-C chemokine receptors using substructural descriptors. Mol. Divers., 2012, 16, 183-191.

[127] Speck-Planche, A.; Kleandrova, V.V.; Rojas-Vargas, J.A. QSAR model toward the rational design of new agrochemical fungicides with a defined resistance risk using substructural descriptors. Mol. Divers., 2011, 15, 901-909.

[128] Speck-Planche, A.; Kleandrova, V.V.; Luan, F.; Cordeiro, M.N. Multi-target drug discovery in anti-cancer therapy: fragment-based approach toward the design of potent and versatile anti-prostate cancer agents. Bioorg. Med. Chem., 2011, 19, 6239-6244.

[129] Tenorio-Borroto, E.; Penuelas Rivas, C.G.; Vasquez Chagoyan, J.C.; Castanedo, N.; Prado-Prado, F.J.; Garcia-Mera, X.; GonzalezDiaz, H. ANN multiplexing model of drugs effect on macrophages; theoretical and flow cytometry study on the cytotoxicity of the antimicrobial drug G1 in spleen. Bioorg. Med. Chem., 2012, 20, 61816194.

[130] Prado-Prado, F.J.; Garcia-Mera, X.; Gonzalez-Diaz, H. Multi-target spectral moment QSAR versus ANN for antiparasitic drugs against different parasite species. Bioorg. Med. Chem., 2010, 18, 2225 2231

[131] Perez-Montoto, L.G.; Santana, L.; Gonzalez-Diaz, H. Scoring function for DNA-drug docking of anticancer and antiparasitic compounds based on spectral moments of 2D lattice graphs for molecular dynamics trajectories. Eur. J. Med. Chem., 2009, 44, 4461-4469.

[132] Prado-Prado, F.J.; Gonzalez-Diaz, H.; de la Vega, O.M.; Ubeira, F.M.; Chou, K.C. Unified QSAR approach to antimicrobials. Part 3: first multi-tasking QSAR model for input-coded prediction, structural back-projection, and complex networks clustering of antiprotozoal compounds. Bioorg. Med. Chem., 2008, 16, 58715880.

[133] Speck-Planche, A.; Kleandrova, V.V.; Luan, F.; Cordeiro, M.N. In silico discovery and virtual screening of multi-target inhibitors for proteins in Mycobacterium tuberculosis. Comb. Chem. High Throughput Screen., 2012, 15, 666-673. 
[134] Speck-Planche, A.; Cordeiro, M.N.D.S. Application of Bioinformatics for the search of novel anti-viral therapies: Rational design of anti-herpes agents. Curr. Bioinform., 2011, 6, 81-93.

[135] Prado-Prado, F.; Garcia-Mera, X.; Abeijon, P.; Alonso, N.; Caamano, O.; Yanez, M.; Garate, T.; Mezo, M.; Gonzalez-Warleta, M.; Muino, L.; Ubeira, F.M.; Gonzalez-Diaz, H. Using entropy of drug and protein graphs to predict FDA drug-target network: theoretic-experimental study of MAO inhibitors and hemoglobin peptides from Fasciola hepatica. Eur. J. Med. Chem., 2011, 46, 1074-1094.

[136] Prado-Prado, F.J.; Ubeira, F.M.; Borges, F.; Gonzalez-Diaz, H. Unified QSAR \& network-based computational chemistry approach to antimicrobials. II. Multiple distance and triadic census analysis of antiparasitic drugs complex networks. J. Comput. Chem., 2009, 31, 164-173.

Received: August 30, 2012 Revised: November 08, 2012 Accepted: November 29, 2012 